\title{
Sûfî Portrelerde İnsanın Kemâl Süreci Nasıl Başlar? Kuşeyri Örneği
}

How does the Moral Competence Process of Human Being Start in Șūfī Portraits 'An Example of al- Qushayrī

Dr.

Aynur SINNGIN

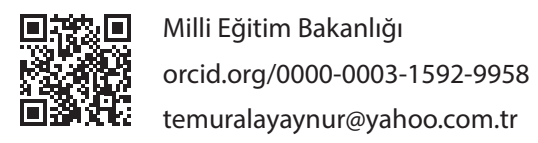




\section{Sufiyge}

50

\section{Öz}

Bu makale tasavvuf literatüründe insanın kemâl sürecinin başlangıcının nasıl resmedildiğini konu edinmektedir. Bu meyanda çalışmamız tasavvufun ‘İnsan nasıl yetkinleşmeye başlar?’ problemine yaklaşımını sûfîlerin tasavvufa yöneliş hikâyelerinden hareketle çözümlemeyi amaçlamaktadır. Makalenin çerçevesi ise Kuşeyrî’nin er-Risâletü'l-Kuşeyriyye adlı eserinin incelenmesiyle sınırlıdır. Çalışmamızın neticesinde ilk olarak insanın yetkinlik sürecinin başlangıcının insanın özne olduğu bir bulmaya değil aksine Allah'ın etkin ve fâil olduğu bir hatırlamaya dayandığı sonucuna ulaşmaktayız. İnsanın başlangıcında sistematik bir tedrîs ve tâlim sürecinin zorunlu olmadığı, bunun yerine duyular, ihlâs üzere amel ve kerâmet gibi unsurların ön plana çıktığını iddia etmekteyiz. Çalışmada ulaştığımız bir diğer netice insanın kemâl sürecinin mihverini oluşturan sürekli değişimin seyri ve akıbeti konusunda sebep-sonuç ilişkisine dayalı bir determinizm yerine indeterminist bir yaklaşımın benimsendiğidir. Bir başka husus sâlikin tasavvufa yönelişini ve sülûk sürecinin başlangıcını ifade etmek için tercih ettiği şu terimlerdir: Tevbe, zühd, terk, Allah'a yönelme ve yeniden Müslüman olma. Son olarak yetkinleşme sürecine giren sâlikin dönüşümünde ön plana çıkan ortak kavramların zühd, sefer/seyahat, mücâvirlik ve sohbet olduğuna işaret etmekteyiz.

Anahtar Kelimeler: Tasavvuf, Kuşeyrî, Risâle, Sûfî Hâl Tercümeleri, Tevbe, Zühd.

\section{Abstract}

This article deals with how the beginning of the perfection process of man is depicted in suufī literature. In this context, our study aims to analyze the approach of șūfîsm to the problem of "How does a person begin to become competent through the stories of Șūfiss?” The framework of the article is limited to the study of al- Risāla al- Qushayrīyya by al- Qushayrī. We first conclude that the beginning of the human competence process is not based on a finding that human is the subject, but on the contrary, on a remembrance that Allah is the agent. We claim that for human beings, a systematic education and training process are not necessary at the beginning, but instead, elements such as senses, good deeds, and miracles come to the fore. Another conclusion of the study is that an indeterministic approach has been adapted instead of determinism based on the cause-effect relationship regarding the course and fate of the continuous change that constitutes the axis of the perfection process of human beings. Another issue is that the terms preferred by the saliq to express his orientation to Süfism, as well as, the beginning of his pathway including tawba, asceticism, abandonment, turning to Allah, and becoming a Muslim again. Finally, we point out that the common concepts that come to the fore in the transformation of the traveler, who has entered the process of becoming competent, are asceticism, spiritual journey and companionship.

Keywords: Taṣawwuf, al-Qushayrī, Risāla, Șūfī State Translations, Tawba, Asceticism. 


\section{Giriş}

ûfî portrelerde ana fikir, insanın daha iyi bir örnekle kendini kıyasla$\checkmark$ yarak, eksikliklerini fark etmesi ve buradan hareketle onları tamamlama yoluna gitmesidir. Bu konuda Ebû Ali Dekkâk'ın (ö. 405/1015) “Şayet (insan) kör değilse kendini mutlaka müşâhede eder" sözü sûfî portrelerin kişinin kendini tanıması için bir ayna işlevine sahip olduğunun bir göstergesidir. Bu anlamda portreler Aristo'nun ifadesiyle 'başka kendi (allos autos)' olarak nitelenebilir. ${ }^{2}$ Dolayısıyla insan, insanda ancak kendini görmek suretiyle varlık zeminini bulur ve buradan hareketle kendi hikâyesini inşâ edebilir. Abdurrahman Câmî̀nin şu sözleri bu konuda temsil gücü yüksek ifadelerdir: "Sûfîlerin hayat hikâyelerini dinlemenin temin ettiği asgari fayda şudur: Kişi bilir ki, kendisinin hâlleri ve fiilleri, onların hâlleri gibi değildir. Kendi kusurların itiraf eder. Riyâdan ve kendini beğenme durumundan kurtulmuş olur.”3 Öte yandan sûfî portreler, tasavvufî düşüncenin başka problemlerinin aydınlatılmasında önemli bir ayraç işlevi üstlenebilir.

İnsanın kemâlinin başlangıcının tasavvuf açısından nasıl resmedildiği konusunda sûfî portrelerden istifade edebiliriz. Kuşeyrî, Risâle'de seksen üç sûfînin portresine yer verir ve bunlar içerisinde sadece on üç kişinin başlangıç hikâyelerini aktarır. Bununla birlikte Risâle'nin geri kalan kısmında yer alan sûfîlerin tasavvufa yöneliş hikâyeleriyle birlikte bu sayı toplamda yirmi sekize ulaşır. ${ }^{4}$ Dolayısıyla sûfîlerin tasavvuf ile irtibatlarının başlangıç noktasından hareketle "İnsan nasıl yetkinleşmeye başlar?" sorusunun tasavvuf açısından yanıtını bulmaya çalışabiliriz. Fakat şunu belirtmek gerekir ki, Risâle’nin sûfî portreler haricinde yer alan başlangı̧̣ anlatıları çoğunlukla Yahudi, Hıristiyan yahut Mecûsî gibi farklı bir dine mensup kişilerin tasavvuf kanalıyla (bir şeyh ya da mürşîd vasıtasıyla) ihtidalarını içermektedir. Bu bakımdan Risâle'deki tasavvuf yoluna giriş anlatılarını iki şekilde kategorize edebiliriz: (a) Müslüman bir kimsenin

1. Abdurrahman Câmî, Nefahâtü’l-Üns: Evliyâ Menkıbeleri, çev. Lâmiî Çelebî, haz. Süleyman Uludă̆ - Mustafa Kara (İstanbul: Marifet Yayınları, Şubat 2001), 48.

2. Hümeyra Özturan, Ahlâk Felsefesinin Temel Problemleri (İstanbul: İlem Yayınları, 2019), 267.

3. Câmî, Nefahâtü'l-Üns, 48.

4. Kuşeyrî̀nin Risâle dışında yer verdiği tasavvuf yoluna giriş anlatıları için bk. Abdülkerîm Kuşeyrî, er-Risâletü'l-Kuşeyriyye, haz. Halil el-Mansûr (Beyrût: Dârü'l-Kütübi'l-İlmiyye1422/2001), 16, 14, 105, 128, 129, 133, 170, 171, 209, 262, 272, 274, 329, 330, 341, 395, 396. 
sülûk sürecine girişi. (b) Farklı bir dine mensup kimselerin bir mürşîd aracılığıyla İslâmiyet'i benimsemesi. ${ }^{5}$ Bu iki anlatı türü arasında bâriz bir farklılık bulunmaktadır. Kuşeyrî, ilkinde, insanın metafizik uyanıŞını (intibâh) duyular ve ihlâs üzere yapılan eylemlerden hareketle izah ederken, din değiştirme anlatılarında ise çoğunlukla başvurulan anahtar kavram kerâmettir. ${ }^{6}$ Bizim hareket noktamız ise Risâle'nin sûfî portreler kısmında yer alan başlangıç hikâyeleri üzerinden erken dönem tasavvuf düşüncesinde insanın kemâl sürecinin nasıl başladığını tespit etmektir. Kuşeyrî̀nin sûfî portrelerde başlangıç hikâyelerine yer verdiği kimseler şunlardır: İbrâhim b. Edhem (ö. 161/778), Zünnûn el-Misrî (ö. 245/859), Fudayl b. İyâz (ö. 187/803), Marûf el-Kerhî (ö. 200/815-16), Bişr el-Hâfî (ö. 227/841), Mansûr b. Ammâr (ö. 225/840), Dâvûd et-Tâî (ö. 165/781), Şakîk el-Belhî (ö. 194/810), Bâyezid Bistâmî (ö. 234/848), Şiblî ve Havvâs.

Bu makalede Kuşeyrî̀nin Risâle'de birbirinden bağımsız şekilde yer verdiği rivâyetler “İnsanın kemâl süreci nasıl başlar?” sorusu etrafında bir araya getirilerek teorik bir çerçeve kurmak amaçlanmıştır. Bu doğrultuda makalenin alt başlıklarını şu şekilde özetleyebiliriz: (1) Kuşeyrî̀nin İnsan Tanımı ve Ahlâkî Yetkinlik Süreci Hakkındaki Tespitleri (2) Kemâl Sürecinin Başlangıcı: Hatırlamak (3) Kademeli Başlangıç Fikri: İslâm’a Giriş, Tasavvufa Yöneliş ve Kemâle Ulaşma. (4) İnsanın Nihai Gayesinin Rızık Değil Marifet Oluşu. (5) İnsanın Kemâl Sürecinin Başlangıcında Duyuların İşlevi: İşitmek ve Görmek. (6) Eylemden Bilgiye, Ümmîlikten Marifete Geçiş. (7) İnsanın Yetkinlik Sürecinde Başlangıç-Son İlişkisi.

5. Kuşeyrî, er-Risâle, 208, 209, 272, 274, 329, 330, 395, 396. Risâle'de yer alan ihtidalardan bir kısmı ise tasavvuftan bağımsız olarak betimlenmektedir. bk. a.mlf, er-Risâle, 170, 171, 262, 341. 6. Kuşeyrî’nin kerâmet aracılığıyla İslâmiyet'i benimseyenlere verdiği örneklerden biri için bk. “İbrâhim b. Acrurî̀nin şöyle dediği hikâye edilir: Bir Yahudi’ye borcum vardı. Bir gün Yahudi borcunu istemek için bana geldi. Kiremit yapmak için kızdırdığım fırının yanında oturmakta idim. Yahudi bana: Ey İbrâhim, bana bir kerâmet göster de o sayede İslâm olayım, dedi. Gerçekten dediğini yapacak mısın dedim? Evet, dedi. O halde elbiseni çıkar dedim. Elbisesini çıkardı. Elbisesini dürdüm, kendi elbisemi de onun elbisesine sardım ve ateşe attım. Sonra bizzat kendim ateşe girdim ve fırının ortasından elbiseyi dışarıya attım ve öbür kapıdan dışarı çıktım. Baktık, elbisem olduğu gibi duruyor hiçbir şey olmamıs. Yahudi’nin elbisesinin ortasında ise bir yanıklık vardı. Bu hali müşâhede eden Yahudi derhal Müslüman oldu.” Kuşeyrî, er-Risâle, 396. 


\section{Kuşeyrî̀nin İnsan Tanımı ve Ahlâkî Yetkinlik Süreci Hakkındaki Tespitleri}

Kuşeyrî (ö. 465/1072) hicri beşinci asırda, sûfîlerin görüşlerinin tasavvuf dışı temâyüllerle karıştırıldığı ve sert bir şekilde tenkit edildiği bir dönemde yaşamıştır. ${ }^{7}$ Bu nedenle, gerek tasavvufa yönelttiği iç tenkitler gerekse 'tasavvufu şeriata yakınlaştırma' konusundaki ${ }^{8}$ gayretleriyle tasavvuf tarihinde temeyyüz eder. Onun tasavvufu sünnî akide çerçevesinde yeniden yorumlaması, ${ }^{9}$ erken dönem tasavvuf düşüncesinde ortaya konan insan tanımlarının seyri üzerinde etkili olmuştur. ${ }^{10}$ Hücvîrî her ne kadar muhakkik sûfîlerin insanın hakikati konusunda nefs, beden ve rûh şeklinde bir tanımda ittifak ettiklerini söylese de ${ }^{11}$ Kuşeyrî, Risâle'de insanı nefs, beden, rûh, kalp ve sir gibi niteliklerin bir bileşkesi olarak resmeder. ${ }^{12}$ Ona göre insanın en önemli özelliği telvîn yani sürekli değişim üzere olmasıdır. ${ }^{13}$ İnsanın tabiatında şu üç unsur bulunur: Ahlâk (huy), haller ve

7. Kuşeyrî, içinde yaşadı̆̆ı toplumda şekil ve kıyafet bakımından sûfîlere benzeyen ve fakat gerçekte mutasavvıf olarak adlandırılmayı hak etmeyen insanların türediğinden bahseder. Bu noktada yitirilen değerlerin, verâ, şeriata ve din bilginlerine hürmet olduğunu bununla birlikte, ibadet ve ameli hafife alan, Allah'da fenâ bulduğu için kendisinden şer'î mükellefiyetlerin düştüğü iddia eden grupların sûfîlerle karıştırıldı̆̆ı için tasavvufa ağır tenkitlerin yöneltildiğini ifade eder. Dolayısıyla er-Risâle' yi yazma gayesinin sahte sûfîler ile gerçek olanları ayırt etmek ve böylece tasavvuf üzerindeki ağır eleştirileri bertaraf etmek olduğunun altını çizer. bk. Kuşeyrî, er-Risâle, 8-9.

8. Süleyman Uludağ, tasavvuf tarihinde Kuşeyrî̀yi özgün kılan düşünüm çerçevesinin 'tasavvufu şeriata yakınlaştırmak' olduğunu belirtir. bk. Süleyman Uludağ, Kuşeyrî Risâlesi (İstanbul: Dergâh Yayınları, 2003), 45-48.

9. Kuşeyrî, "Sûfîlerin Akâit ve Tevhit Meseleleri Hakkındaki İnançların Açıklanması" başlıklı bölümde yirmi yedi sûfîden naklettiği rivayetlerin hepsinin tek bir noktaya işaret ettiğini yani tasavvufun akâid bahsinde sünnî düşünce ile uzlaşı içinde olduğunu söyler. Dolayısıyla Kuşeyrî, sûfî şeyhlerin ittifakla serdettikleri görüşlerin, savunduğu iddia için kuvvetli bir delil olabileceğini düşünmektedir. bk. Kuşeyrî, er-Risâle, 19.

10. Tasavvuf düşüncesinde "İnsanın tanımı nedir?" sorusuna yanıt arayan öncü bir yazı için bk. Hacı Bayram Başer, "Yükümlü Varlıktan Varlığın Gayesi Olan İnsana: Tasavvufta İnsan Tanımlarının Dönüşümü Üzerine”, İnsan Nedir?: İslâm Düşüncesinde İnsan Tasavvurları, ed. Ömer Türker - Halil İbrahim Üçer (İstanbul: İlem Yayınları), 501-544.

11. Hücvîrî, nefsin işlevinin arzu ve istekler anlamından hevâ, bedenin duyular, rûhun fonksiyonun ise akıl olduğunu söyler. bk. Hücvîrî, Keşüll-Mahcûb: Hakîkat Bilgisi, haz. Süleyman Uludağ (İstanbul: Dergâh Yayınları, 1996), 311.

12. Kuşeyrî, er-Risâle, 123; Bedriye Reis, "Kuşeyrî̀nin Letâifü'l-İ̧ârâtı Bağlamında Kalbin İdrâki”, İnsan ve Toplum Bilimleri Araştırma Dergisi 8 (2019) , 556.

13. Bu konuda Kuşeyrî, Cüneyd'den şu rivâyeti aktarır: "Sâdık günde kırk kalıba (şekle) girer, mürâî ise kırk sene bir hâl üzere kalır.” Bu söz, sûfîlerin insan tanımlarının sürekli bir değişim (telvîn) zemininde tanımladıklarının bir göstergesidir. Sûfînin kemâl yolculuğunun dünyevî 
(irâdî) fiiller. ${ }^{14}$ Kuşeyrî̀ye göre her insan doğuştan değişime açık belli bir ahlâk ile dünyaya gelir. Öte taraftan Allah, insana vehb̂̂ olarak sürekli haller gönderir. Şayet insan cehd ve gayretiyle niyetini saflaştırmak suretiyle (ahlâkî eylemlerinin gerekçesini sadece Allah’a tahsis ederek) erdemli eyleme yönelirse Allah hem kendisine gönderdiği halleri saflaştırır hem de söz konusu sâlih ameli gerçekleştirmesine imkân verir. Böylece insan epistemik ve ahlâkî olarak yetkinleşmeye başlar. Kuşeyrî̀nin insanın ahlâkî olgunlaşması için sunduğu bu çözümleme modeli Eş’arîlerin kesb teorisini akla getirmekle birlikte ${ }^{15}$, buradaki esas vurgu insanın kemâl sürecinde gerçek öznenin insan yerine Tanrı olduğunun vurgulanmasından ibarettir.

Kuşeyrî̀de dikkati çeken bir diğer husus, insanın kemâlinde tasavvufun işlevine yaptığı güçlü vurgudur. Ona göre tasavvuf nafile ibadetlerin çoğaltılması, uzun açlık oruçları yahut aşırı riyâzet usullerinden ibaret değildir. ${ }^{16}$ Nitekim Kuşeyrî̀ye göre söz konusu katı zühd pratikleri sanıldığının aksine gerçekleştirilmesi kolay uygulamalardır. Asıl zor olan ise insanın niyetini saflaştırmasıdır. ${ }^{17}$ Dolayısıyla tasavvufta gaye insanın niyet, irade ve eylemlerinin gerekçesinin mahza Tanrı kılınmasıyla

şartlarda belli bir sonu yoktur. Bu yaklaşım aynı zamanda dairesel bir kemâl nazarîyesiyle neticelenecektir.

14. Kuşeyrî insanın fiillerini "kulun iradesine dayanan tasarruflar" olarak tanımlamaktadır. bk. Kuşeyrî, er-Risâle, 103. Bununla birlikte, tasavvuf literatüründe insanın eylemlerinin gerçek öznesi Allah olarak betimlenir. Bunun için geliştirilen çözümleme ise Allah tarafından verilen kudret sayesinde insanın eylemini gerçekleştirebildiğidir. Hücvîrî, Allah'n insana verdiği kudretle eylemde bulunmasını tevfîk terimiyle ifade eder. bk. Hücvîrî, Kesfǘl'-Mahcûb, 81 .

15. Kuşeyrî̀nin kelâm yaklaşımı için daha detaylı bilgi için bk. Abdülkerîm Kuşeyrî, "Lüma fi'l-İtikad”, çev. Ercan Alkan, Tasavvuf: İlmîve Akademik Araştırma Dergisi 12/28 (2011), 193-198; İsmail Şık, "Kuşeyrî̀nin "Luma' fi'l-İtikâd” Adlı Akâid Risalesinin Çeviri ve Değerlendirilmesi", Çukurova Üniversitesi İlahiyat Fakültesi Dergisi 8/2 (Temmuz-Aralık, 2008), 210; İsmail Şık, "Bir Mutasavvıf Olarak Kuşeyrî̀nin Kelâmî Görüşleri”, İslâmi İlimler Dergisi 4/1-2 (2009), 257-274; Ömer Yllmaz, İbrahim Kurani Hayatı, Eserleri ve Tasavvuf Anlayı̧̧ı (İstanbul: İnsan Yayınları, 2005), 365-371.

16. "Zâhirde çok evrâd ve ezkâr sahibi olmak müritliğin adâbından değildir. Çünkü sûfîler iyi amelleri çoğaltmak için değil, hâtır ve kalplerini dünyevi ve maddi kaygıllar (havâtır)dan boşaltmak, huylarını terbiye etmek ve gönüllerinden gafleti kovmak için uğraşır ve didinir dururlar. İyi ve salih amelleri sadece behemehal eda edilmesi şart olan farzlarla bunlara tabi olan revâtib sünnetler ölçüsünde tutarlar. Sûfîlere göre kalp ile zikri devam ettirmek, fazla miktarda nafile namaz kılmaktan daha mükemmel bir hâldir." Kuşeyrî̀, er-Risâle, 430.

17. "Avam ameli mükemmel yapmak için çabalar. Havâsın maksadı ise manevi halleri saf vaziyete getirmektir. Zira açlığa göğüs germek ve uykusuz kalmak kolay ve basittir. Halbuki huyları tedavi ile değiştirmek ve süflî arzulardan arınmak zor ve sıkıntılı bir iştir." Kuşeyrî, er-Risâle, 135. 
alakalıdır ki bunun anlamı tevhîdde yakîn sahibi olmaktır. Tasavvuf düşüncesinde tevhîd ise insanın nihai gayesini oluşturur.

Risâle'nin sonunda yer alan Adâbül-müridîn başlıklı bölüm insanın nihai gayesine nasıl ulaşacağı konusunda son derece sistematik bir içeriğe sahiptir. Kuşeyrî, öncelikle yetkinleşmek isteyen insan için bu konuda tasavvuftan başka bir yol olmadığının altını açık bir şekilde çizer. ${ }^{18}$ Dolayısıyla sâlik tasavvuf dışındaki farklı mezheplere yönelmek yerine liyakat sahibi bir mürşîdin eşiğine oturmalıdır. ${ }^{19}$ Kuşeyrî, bu noktada hocası Ebû Ali Dekkâk'a referansla mürşîdsiz yola çıkan müridi meyve vermeyen bir ağaca benzetir: "Yetiştireni ve dikeni olmadan kendi kendine ve hüdâyinâbit olarak biten bir ăgaç yaprak açar, fakat meyve vermez. Nefes nefese ve tedricî bir surette tarikatın adâbını ögretecek bir üstâda sahip olmayan müridin durumu da böyledir. Bu durumda olan mürid hevâ ve hevesine tapar, başka bir kurtuluş yolu bulamaz." ${ }^{20}$ Kuşeyrî daha sonra, müridin uyması gereken birtakım ilkeler vazeder ki, sâlik ancak bu şartları yerine getirdikten sonra tasavvufî yöntem ve metodu uygulayabilir. Kuşeyrî̀nin sâlik için zikrettiği şartlar şöyledir: (a) İlk olarak şeriat ilimlerini tahsil etmesi gerekir. (b) Tevbe etmeli ve varsa hasımlarıyla helalleşmelidir. (c) Mal ve mevki konusunda zühd sahibi olmalıdır. (d) İnsanların kendisi hakkındaki övgüyle yergisini eşit görmelidir. (e) Mürşîde hiçbir konuda muhâlefet etmemelidir. ${ }^{21}$ (f) Mürid sırrını mürşîdi

\footnotetext{
18. "Bir müridin bu yolun ehli olmayanlardan birinin mezhebine intisâp etmesi çirkin bir şeydir. Bir sûfînin, sûfîyye tarikatı dışındaki muhtelif mezheplerden birine intisâp etmesi tasavvuf yolunun ehli olanlarının mezhepleri hakkındaki cehâletinin neticesidir. Çünkü sûfîlerin ortaya koydukları meseleler hakkındaki delilleri, herkesin delilinden daha açıktır. Tasavvufî mezheplerin kâide ve esasları diğer bütün mezheplerin kâide ve esaslarından daha kuvvetlidir. İnsanlar ya nakil ve eser sahibi veya akıl ve fikir erbâbı olur. Bu tâifenin şeyhleri bu iki yolun da üstüne çıkmışlardır. Halk için gayb olan şey onlar için ayân beyândır. Halk için gaye olan bilgiler onlarda Hakk Teâlâ’dan ihsân olarak mevcuttur. Sûfîler vuslât ehli iken halk istidlâl ehlidir.” Kuşeyrî, er-Risâle, 424. Benzer bir düşünceyi Cüneyd-i Bağdâdî, "Gökkubbenin altında bizim ilmimizden daha değerli bir ilim olduğunu bilsem, dinlemek için ona ve ehline koşardım” sözleriyle ortaya koyar. bk. Ebû Nasr Serrâc, el-Lüma': İslâm Tasavvufu, haz. H. Kâmil Yılmaz (İstanbul: Erkam Yayımları, 2019), 204.

19. Kuşeyrî, sâlikin bulunduğu yerde ona yol gösterebilecek bir mürşîd olmadı̆̆ bulunan bir yere hicret etmesinin zorunlu olduğunu söyler. bk. Kuşeyrî, er-Risâle, 430-431.

20. Kuşeyrî, er-Risâle, 426-427.

21. Kuşeyrî her ne kadar müridin mürşîde muhâlefet etmemesi gerektiğini söylese de sâlikin şeriata uygun olmayan bir durumla karşılaştığında hüsnüzan ile şeyhini terk etmesi gerektiğinin de altını çizer. "Şeyhlerin masûm olduklarına müridlerin itikat etmemeleri lazımdır. Mürid onları halleri ile baş başa bırakır. Haklarında hüsnüzanda bulunur. Kendisine teveccüh eden
} 
hariç herkesten saklamalıdır. ${ }^{22}$ Sâlik bu şartları yerine getirdikten sonra, mürşîd kendisinden halvet-uzlet ile zikir olmak üzere iki yöntemi uygulamasinı ister.

Mürşî̀d, öncelikle müridden söz konusu manevi sülûk sürecinden dönmeyeceğine dair bir ahid (söz) alır. Aksi takdirde Kuşeyrî sülûka başlayan sâlikin süreç içerisindeki bir anlık duraksamasını, gevşeklik göstermesi yahut gerilemesinden daha tehlikeli görmektedir. Bu nedenle "Sülûkunun başlangıcında duraklayan bir müritten artık hayır gelmez" ${ }^{23}$ diyerek ahitleşmenin önemine dikkat çeker. Kuşeyrî bundan sonra mürşî̀din müride önce dil zikri daha sonra ise kalp zikri telkîni vereceğini söyler. ${ }^{24}$ Dil ile kalp zikrinin uyumlu olmasından maksat, sâlikin niyet, irade ve eylemlerinde tutarlı olmasını sağlamaktır. Bu anlamda tasavvufun maksadı insanda zâhir-bâtın, iç-dış, niyet-amel uyumunun sağlanmasıdır. Zikir için en uygun ortam sâlikin halvet-uzlet içerisinde bulunabileceği bir mekândır. Kuşeyrî, halvet ve uzleti, insanın toplumdan uzak kaldığı zaman ancak kendi doğasına yönelebileceği için tavsiye eder. Ona göre inzivâ haline çekilen insanda manevî bir durgunluk yerine maruz kaldığ 1 havâtırın etkisinin artmasıyla birlikte çetin bir çatışma hali açığa çıkar. Bu noktada mürşîdin müride tavsiyesi havâtır ile meşgul olmak yerine zikre devam etmesi yönündedir. ${ }^{25}$ Tüm bu süreçte sâlik, mürşîdin kendisine tavsiye ettiği kurallara titizlikle riâyet ederse ancak ahlâkî yetkinliği gerçekleşir. ${ }^{26}$ Peki tasavvuf düşüncesine göre insanın ilk kemâl süreci nasıl başlamaktadır?

mükellefiyetler konusunda Allah Teâlâ ile aralarında bulunan hudut ve ahkâma riâyet eder. İlletli olan ile sıhhatli olan arasındaki farkı görmek için ilmi kâfidir.” bk. Kuşeyrî, er-Risâle, 431. 22. Kuşeyrî, er-Risâle, 426-428.

23. Kuşeyrî, er-Risâle, 428. Kuşeyrî, ayrıca müridin Allah ile muâhede yani şu kadar nâfile ibadet edeceğim diye ahitleşmemesi gerektiğini vurgular. Nitekim, sâlik böyle bir ahitleşme yapar ve sonrasında yerine getirmezse, bunun bir tür ruhbanlık olacağını söyleyerek Kur'ân'dan şu âyete yer verir: "Kendilerine farz kılmadığımız bir ruhbanlık icat ettiler, sırf Allah rızası için icat ettikleri bu ruhbanlığa hakkıyla riâyet edemediler.” (el-Hadîd 57/28) bk. Kuşeyrî, er-Risâle, 435.

24. Kuşeyrî, er-Risâle, 428.

25. Kuşeyrî, er-Risâle, 429.

26. Kuşeyrî̀nin yer verdiği kurallar için bk. Kuşeyrî, er-Risâle, 429-435. 


\section{Kemâl Sürecinin Başlangıcı: Hatırlamak}

“Bir Melik'in oğlu idi. Bir gün ava çıkmış, ininden çıkardığı bir tilkiyi veya bir tavşanı takip ederken birden hâtiften gelen bir ses ona: 'Ey İbrâhim sen bunun için mi yaratıldın?! Bu işi yapmayı mı memur kılındın?!' diye hitâp etmişti. Sonra eğerinin ön kaşından bir ses ona: 'Vallahi sen ne bunun için yaratıldın, ne de bunu yapmakla emrolundun!' dedi. Bunun üzerine atından indi. Babasının çobanlarından birine rastladı. Çobanın sûftan yapılmış cübbesini aldı, sırtına giydi. Atıyla birlikte yanında bulunan herşeyi çobana verdi. Sonra sahranın yolunu tuttu ve Mekke'ye geldi. Burada Süfyân es-Sevrî (ö. 169/785) ve Fudayl b. İyâz gibi zâhitlerle dostluk kurdu. Daha sonra Şam'a geldi ve burada vefat etti." ${ }^{27}$

Yukarıda verilen İbrâhim b. Edhem'in ${ }^{28}$ hikâyesinde ilk dikkati çeken husus, insanın kemâl sürecinin bir soruyla başlamasıdır. İnsanın niçin yaratıldığı yahut nihai varoluş gayesinin ne olduğu sorusu, tasavvuf düşüncesinin esas mevzusunu teşkil eder. Bununla birlikte, sûfîlere göre dinin maksadı, insanın varoluş amacını hatırlaması ve buna uygun bir yaşam sürmesidir. Bu çerçevede, kelâm daha çok dinin itikatla ilgili spekülatif sorunlarına eğilirken, fıkıh ise normatif birtakım uygulamalar ile kendini sınırlar. Tasavvuf ise fikıh ve kelâm okulları tarafından ihmal edilen bir konuya yani dinin maksadı ile insan arasındaki ilişkiye dikkatleri çeker. Dolayısıyla “Ey İbrâhim! Sen bunun için mi yaratıldın?” sorusu hem tasavvuf düşüncesinin varlık sebebini açıklayan hem de sûfîlerin insan tanımlarını tayin eden bir içeriğe sahiptir. Fakat burada dikkati çeken bir diğer husus, İbrâhim b. Edhem'in metafizik uyanışının sistematik-nazarî bir arayışın sonucunda bulma şeklinde değil de anlık bir hatırlamayla gerçekleşmesidir.

Burada üzerinde durulması gereken iki husus vardır. İlki, hatırlama teriminin tasavvuf düşüncesinde karşılık bulduğu anlamdır. Özellikle Cüneyd-i Bağdâdîyle (ö. 297/909) birlikte insanın nihai gayesinin olmazdan

27. Kuşeyrî, er-Risâle, 22-23; Hücvîrî, Keş̧üll-Mahcûb, 201.

28. İbrâhim b. Edhem'in hayatı ve tasavvuf düşüncesindeki yeri için bk. Halime Gül, İbrahim b. Edhem ve Tasavvuf Tarihindeki Yeri (Konya: Selçuk Üniversitesi, Sosyal Bilimler Enstitüsü, Yüksek Lisans Tezi, 2008), 15-22. 
önceki ilk hale dönmek ${ }^{29}$ şeklinde ifade edilmesi, sûfîlerin hakikat arayış1$\mathrm{n}$ ileriye dönük bir arama ve keşften ziyade geriye dönük bir anımsama şeklinde betimlemelerine yol açmıştır. Bir diğer husus ise, hatırlamanın sistematik bir tedrîs ve tâlim sürecine dayanmamasıdır. Risâle’ de yer alan başlangıç anlatılarının neredeyse hiçbirinde, sâlikin özel olarak sistematik bir eğitim aldığına dair herhangi bir ifadenin olmaması bunun bir göstergesidir. Bu durum erken dönem tasavvuf düşüncesinde $\ddot{u} m m \hat{\imath}$ şeyh kavramsallaştırılması şeklinde karşımıza çıkmaktadır. ${ }^{30}$ Kuşeyrî, Risâle'nin Âdâbül-müridîn kısmında, sûfîleri ümmî ve imam olmak üzere iki şekilde kategorize etmektedir. Bu konuda Ahmed b. Hanbel'in ümmî bir şeyhi imtihân etmesi ve sonrasında yaşadığı hayret ve pişmanlığa dair bir rivâyete yer verir. ${ }^{31}$ İnsanın zâhiri ilimlere ihtiyaç duyup-duymaması noktasında Kuşeyrî̀nin tavrı aynı zamanda diğger dini düşünce okullarına yönelik negatif bir eleştiriyi de içerir. Bu meyanda, Kuşeyrî sâdık müridin ulemanın ilmine ihtiyaç duymayacağını söylemesi dikkat çekicidir. ${ }^{32}$

29. Cüneyd-i Bağdâdî, Resâilü’l-Cüneyd, thk. Ali Hasan Abdülkadir (Kâhire: Darü'l-Kütübi’lMısriyye 1988), 2. Ayrıca elest misâkının tasavvufî düşüncede nasıl yorumlandığına dair yetkin bir makale için bk. Muammer Cengiz, “Tasavvuf Tarihinde Elest Misâkına Dair Yorumlar”, Uluslararası Sosyal Araştırmalar Dergisi 10/50 (Haziran 2017), 906-907.

30. “Tasavvuf bir yandan bilim haline gelmek istiyor, öte yandan müntesipleri arasından bilim yapabilme kabiliyeti olmayan insanların bulunabileceğini ve hatta bunların en ileri makamlara ulaşabileceğini kabul ediyordu. Bu çelişki tasavvuf tarihinde sürekli ortaya çıkan bir çelişkidir. Etkili sûfîlerin önemli bir kısmı tabii olarak bilim geleneğinden gelmeyen ve hatta bilim yapabilecek bir kâbiliyete sahip olmayanlardı.” Ekrem Demirli, “Kuşeyrî̀den İbnü’l Arabî̀ye İşârî Yorumculuk Hakkında Bir Değerlendirme: İşârî Yorumdan Tahkîke Doğru Kur'ân-1 Kerim Yolculuğunun Gelişimi”, Atatürk Üniversitesi İlahiyat Fakültesi Dergisi 40 (2013), 141-142.

31. "Ahmed b. Hanbel, Şafîi (r.a) ile birlikte oldukları bir sırada Şeybân Râî yanlarına geldi. İmam Ahmed, İmam Şafî̂’ye: İlmin eksikliği konusunda şu zâtı uyaracağım. Böylece belki ilim tahsîl etmekle meşgul olur, dedi. Şafîi: Hayır, bunu yapma dedi. Fakat İmam Ahmed'i ikna edemedi. İmam Ahmed, Şeybân'a: Bir gün ve bir gece beş vakit namazından birini kılmayı unutan ve unuttuğu namazın hangisi olduğunu bilmeyen kimse üzerine farz olan nedir? Bu hususta görüşün nedir ey Şeybân, dedi. Şeybân: Ey Ahmed, bu Allah Teâlâ'dan gâfil olan bir kalptir. Bu hususta farz olan bir daha Mevlâ'sından gâfil olmaması için bu kalbi edeplendirmek ve terbiye etmektir. Bu cevabı alan Ahmed, baygın bir şekilde yere düştü. Kendine gelince İmam Şafiî (r.a) ona: Ben sana bu zâtı tahrîk etme dememiş miydim? dedi. Şeybân Râî, sûfîlerin ümmîlerinden idi. Ümmî sûfînin hali bu olunca imam olan bir sûfînin hali ne olur, bir düşünün!” Kuşeyrî, er-Risâle, 425-426.

32. Kuşeyrî, er-Risâle, 238. Kuşeyrî’nin hadis, fikıh ve kelâm sahasındaki ilmi otoritelere yönelik söz konusu olumsuz eleştirisi, 'kurrâ ticareti yapanlar' ile 'devlet adamlarına yakın olan ulema’ şeklindeki eleştirileri; a.mlf., er-Risâle, 136-137. Esasında niyet-eylem birlikteliğinin bozulmuş olduğunun bir göstergesidir. Daha açık ifade etmek gerekirse, Kuşeyrî tek başına teorik ilmin elde edilmesinin insanı yetkinleştirmeyeceğini düşünmektedir. Bu nedenle, sûfî hâl 
İnsanın en son gayesini hatırlaması ile ilgili irtibatlı bir diğer mesele, söz konusu hatırlama sürecinin gerçek öznesinin kim olduğudur. Kuşeyrî̀nin aktardığı anlatıya göre, İbrahim b. Edhem, hâtiften gelen bir ses ${ }^{33}$ ile metafizik bir uyanış yaşamaktadır ${ }^{34}$ ve daha önceki yaşamına dair herhangi bir ipucu verilmemektedir. Şu halde onun yetkinleşme sürecinin başlangıcı kendi cehd ve gayreti ile mi yoksa Allah'ın inâyeti ile mi gerçekleşmektedir? Erken dönem İslâm düşüncesi içerisinde insanın iradesi ile eylemleri arasındaki ilişkinin analizinde, tasavvufun muhâtapları ve muhâlifleri olmak bakımından dört yaklaşımdan bahsedilir: (a) Cebrîyye (b) Mu’tezîle (c) Eş'arî ve (d) İbâhî zümreler. Cebrîyye'nin yaklaşımı, insanın eylemlerinin yegâne fâilinin Allah olduğu ve bu nedenle insanın özgür olmadığ̣ yönünde iken; Mu’tezîle’nin savunduğu görüş ise insanın eylemlerinde mutlak anlamda özgür olduğudur. Eş’arîlerin yaklaşımı ise Cebrîyye ve Mu'tezîle arasında bir ara çözüm olarak temeyyüz eder. Özellikle eylemlerin yaratıcısı anlamında yegâne fâilin Allah ve fakat fiillerin kâsibinin ise insan olduğu şeklindeki kesb teorisi, Eş’arîlerin hem insanın irâdesini hem de Allah'ın mutlak fâil ve kudret sahibi oluşunu birlikte muhâfaza etmek için geliştirdikleri bir öğretidir. Tam olarak kim/ler tarafından temsil edildikleri belli olmayan İbâhîlere gelince, bu yaklaşımın odak noktası, zühd gibi birtakım eylemler neticesinde kemâle eren insandan teklîfin (sorumluluğun) düşeceğidir. ${ }^{35}$

Kuşeyrî̀nin bu soruna yaklaşımı ise birden fazladır. Risâle'nin muhtelif yerlerinde farklı çözümleme teknikleri sunar. Bunlardan ilki bir önceki bölümde bahsettiğimiz, ahlâk (huy), hâller ve (irâdî) fiiller yorumudur. Buna göre İbrâhim b. Edhem'in metafizik uyanışı Allah'ın inâyeti ile olabilir. Onun bu konudaki yaklaşımı havâtır görüşü ile ilişkilidir. Kuşeyrî, Risâle'de havâtırı kalplere (zamâir) gelen bir hitâp anlamında dört kategoride ele alır: (a) Melek'ten gelen ilhâm. (b) Şeytan'dan gelen visvâs.

tercümelerinde yer verdiği başlangıç hikâyelerinde, dini ilimlerde teorik olarak otorite sahibi olmayı elzem bir şart olarak görmediği için yer vermez.

33. Hücvîrî, İbrahim b. Edhem'e "Sen bunun için mi yaratıldın?” şeklindeki hitâbın, av esnasında Allah'ın ceylanı konuşturması sebebiyle gerçekleştiğini aktarır. bk. Hücvîrî, Keşfü’l-Mahcûb, 201. 34. Batılı araştırmalarda İbrahim b. Edhem'in tevbe etme süreci bir tür ihtida (conversion) olarak değerlendirilmesinin yanı sıra sıklıkla Buddha ile karşılaştırılmaktadır. bk. Atif Khalil, "A Note on Interior Conversion in Early Sufism and Ibrahım b. Adham's Entry into the Way", Journal of Sufi Studies, 5/2 (Nowember 2016), 189-198.

35. Başer, Şeriat ve Hakikat, 103. 
(c) Nefs'ten gelen hevâcis. (d) Allah'tan gelen hâtır-1 Hakk. ${ }^{36}$ Kuşeyrî şeytandan ve nefsten gelen hâtırların kendilerini kabul ettirmek için israrcı olmasına karşın kişinin mezkûr havâtırı kabul edip etmeme noktasinda muhayyer olduğunu söyler. Benzer şekilde melekten kaynaklanan hâtırın karşısında insanın konumunu yaptı̆̆ı tercih belirler. Allah'tan gelen hâtır-ı Hakk karşısında ise insan savunmasızdır yani zorunlu olarak tâbi olur. Bu anlamda hâtır-ı Hakkın etki altına alma ve yönlendirici etkisi bulunmaktadır. Risâle'deki başlangıç anlatılarının en ilginç tarafı, neredeyse tüm sûfîlerin işittikleri sese yahut hatırlamaya zorunlu olarak tâbî olmalarıdır. Daha açık ifade etmek gerekirse ne İbrâhim b. Edhem ne de diğer sûfîler işittikleri havâtıra aykırı hareket etmemektedirler. Dolayısıyla İbrâhim b. Edhem'in işittiği sesin Allah'tan gelen bir havâtır olduğunu söylemek mümkündür.

Kuşeyrî̀nin bir başka izah biçimi ise Allah'tan gelen hitâbı kerâmet olarak betimlediği satırlardır. Risâle'de kerametleri zikrederken "hâtiften bir hitâbın işitilmesi”ne de yer verir. İlerleyen satırlarda ise kerâmetin ortaya çıkmasındaki maksadın tevhîdde yakîni arttırmak olduğunu söyler. ${ }^{37}$ Kerâmeti tabiattaki nedenselliğin bozulması şeklinde ele alacak olursak, bu anlamıyla insanın hâtiften bir ses işitmesini Allah ile sebeplerden bağımsız iletişime geçmesi olarak yorumlayabiliriz. Görüldüğ̈ü üzere Kuşeyrî’nin tüm yorumlarında odaklandığı husus insanın yetkinlik sürecinin başlangicında Allah'ın etkin ve fâil bir özne olarak bulunduğunu vurgulamaktır. Peki insan söz konusu süreçte irâdî hiçbir tasarrufta bulunmamakta m1dır? Bu konuda Kuşeyrî̀nin Risâle' de yer verdiği irâde bahsine atıfta bulunabiliriz. Kuşeyrî, insanın yetkinlik sürecinde mutlak anlamda edilgin ve pasif olduğunu söylemiyor aksine son derece aktif bir sorumluluklar manzumesini insana yüklüyor. Hatta Ebû Ali Dekkâk'tan rivayetle, sülûkunun başlangıcında mücâhede sahibi olmayanların bu yolun kokusunu bile koklayamayacaklarını aktarması bunun bir göstergesidir. ${ }^{38}$ Fakat Kuşeyrî aktif bir dil kullanımını, ahlâkî neticeleri bakımından mahzurlu görüyor olabilir. Bu durum tasavvufta Ebû Saîd el-Harrâz'ın "Kim çaba harcayarak maksadına ulaşacağını zannederse kendisini boşuna sıkıntıya sokar. Kim çaba sarf etmeden maksadına vasıl olacă̆ını zannederse kuru 
bir temenninin peşinde koşar ${ }^{\prime 39}$ şeklindeki paradoksal söylemi ortaya çıkarır. Dolayısıyla, Kuşeyrî insanın yetkinlik sürecinin her ne kadar Allah'ın inâyeti sayesinde başlatıldığını imâ etse de süreç içerisinde insanın cehd ve gayretini aktif kılan bir yaklaşımı benimsemektedir.

İbrâhim b. Edhem'in başlangıç hikâyesinde işaret etmemiz gereken bir diğer husus, anlık metafizik uyanışının akabinde terk ettiği ve yöneldiği unsurlardır. Bunlar zühd, çöle seyahat ve sûfîlerle sohbet olmak üzere üç şekilde özetlenebilir. Üzerindeki elbiseleri çobanın yünden (sûf) abasıyla ${ }^{40}$ değişmesi Belh'te sahip olduğu makamı terk etmesi anlamına gelmektedir. Öte yandan onun hakkındaki diğer anlatılar, çölde seyahat boyunca hayatta kalacak kadar bir rızıkla yetindiğini göstermektedir. İbrâhim b. Edhem'in hikâyesinde zühd ile ilgili ön plana çıan bu iki unsur, biri idârî mevkilerde görev almaya karşı diğeri ise zenginleşmeye ve kesbe karşı bir zühd anlayışının izleri olarak yorumlanabilir. Nitekim Kuşeyrî, Âdâbü'l-müridîn'de tasavvuf yoluna giren sâlikin ilk önce yapması gereken şeylerden birinin önce mal daha sonra mevki olmak üzere terk etmesi anlamında zühd olduğunu söyler. ${ }^{41}$

İbrâhim b. Edhem'in çöle seyahat etmesinin, biri kırsal kesimde (çöl) tasavvuf diğeri ise ahlâkî olgunlaşmada bir yöntem olarak seyahat şeklinde iki boyutu bulunmaktadır. Erken dönem tasavvuf düşüncesinde, katı zühd yaklaşımını benimseyen sûfîler zorunlu bir çöl hayatının insanı yetkinleştireceğini düşünmekteydiler. Bu nedenle şehir yaşamından uzak bir tasavvuf yaklaşımını benimsediler. Böylece Hz. Peygamber'in manevi şahsiyetine komşu olmak anlamına gelen mücâvirlik geleneğini başlamı̧ oldu. ${ }^{42}$ Nitekim İbrâhim b. Edhem'in başlangıç hikâyesinde yer

39. Kuşeyrî, er-Risâle, 15.

40. İbrahim b. Edhem'in hikâyesinde tasavvuf yoluna girişinin kıyafet değişimi gibi sembolik bir anlatı üzerinden gerçekleştirilmesi, akla, tasavvuf tanımının sûf ile olan köken birlikteliğini getirmektedir. Tasavvufun niçin bu adla anıldığı meselesi erken dönem tasavvuf kaynaklarında açık ve net olarak ifadesini bulmamakla birlikte, Kuşeyrî, hâl tercümelerinin girişinde, sûfîlere başlangıçta zühhâd ve nüssâk denildiğini ve fakat diğer bazı grupların da kendilerini zâhit olarak tanımladıkları için bir kavram kargaşasının ortaya çıktığını belirtir. Bu nedenle tasavvufun gerçek anlamının “Her nefeste Allah ile olma hâli” olduğunu söyleyerek, kelimenin her ne kadar yün giymekle yani zühd ile bir irtibatı olsa da esasında gerçek anlamının bu olmadı̆̆ı yani kişinin niyet ve eylemlerini hiçbir boşluk bırakmayacak şekilde her an Allah'a tahsîs etmesi olarak anlaşılması gerektiğinin altını çizmektedir. bk. Kuşeyrî, er-Risâle, 21.

41. Kuşeyrî, er-Risâle, 484.

42. Başer, Şeriat ve Hakikat, 84-85. 
alan çöle seyahat ve mücâvirlik bunun bir göstergesidir. ${ }^{43}$ Fakat ilginç bir şekilde, Kuşeyrî, Âdâbü'l-müridîn'de sülûk eğitiminin başlangıcındaki sâlikin seyahat etmesini olumsuzlamaktadır. Sefer ancak genç müritler için yahut rehberlik edecek bir mürşîd bulunmadığ 1 durumlarda zorunlu görülebilir. Nitekim ona göre yolculuğun hakikati, kötü huyları terk etmek suretiyle iyi huylara doğru yapılan bir seferden ibarettir. ${ }^{44}$ Dolayısıyla Kuşeyrî açısından insanın yetkinleşmesi için zorunlu bir çöl yaşamına gerek yoktur. Aksine şehir hayatında tasavvuf uygulanması mümkün bir terbiye yöntemidir. ${ }^{45}$

Son olarak, İbrâhim b. Edhem'in çöldeki tasavvuf yaşamında kendisine eşlik eden sûfîler ile oluşturduğu sohbet ortamına değinmek gerekir. Bir yöntem olarak sohbet, erken dönem tasavvuf düşüncesinde insanın yetkinleşmesi meselesinde başvurulan yöntemsel araçlardan biridir. ${ }^{46}$ Kuşeyrî, sohbetin ikisi dikey (ast-üst ilişkisi) diğeri ise yatay (akran ilişkisi) olmak üzere üç boyutu olduğunu söyler. ${ }^{47}$ İlki, sâlikten mürşîde doğru gerçekleşen sohbettir ki, bunun esası hürmet, hizmet ve muhâlefet etmemektir. İkincisi yani şeyhten müride doğru olan sohbette ise, müridin hatalarının söylenmesi ve şefkat esastır. Yatay boyutta tanımlanan sohbet yani akran sûfîler arasında ise isâr ve mahabbet esastır. ${ }^{48}$ Bununla

43. Kuşeyrî, sûfî portreler haricinde aktardığı bazı başlangıç hikâyelerinde mücâvirlik meselesine işaret eder. bk. "Bir gün vezir Ali b. Mûsa ihtişamlı bir alayla birlikte atına binmiş gidiyordu: Onu tanımayanlar hayretlerinden bu kimdir? Bu kim imiş? demeye başladılar. Yolda duran bir hanım: Ne zamana kadar bu kimdir, bu kim imiş diyeceksiniz. Bu Allah’ın gözünden düştüğü için gördüğünüz biçimde Allah’’n belâya soktuğu bir kimsedir, dedi. Bu sözü işiten Ali b. Mûsa evine döndü, vezirlikten istifa etti. Mekke’ye gitti ve orada mücâvir hayatı yaşadı.” Kuşeyrî, er-Risâle, 133.

44. Sefer kavramını felsefe ve tasavvuf açısından mukayese eden disiplinler arası bir yazı için bk. Mahmut Meçin, “Felsefe ve Tasavvufta Sefer Metaforu: Aklî ve Manevî Yolculuk”, Atatürk Üniversitesi İlahiyat Fakültesi İlahiyat Tetkikleri Dergisi 54 (2020), 329-353.

45. Kelâbâzî, memleket memleket dolaştıkları için erken dönemdeki sûfîlerin "Seyyâhîn" (Seyyahlar) şeklinde adlandırıldıklarını söyler. bk. Kelâbâzî, Ta'arruf, 60.

46. Frietz Meier, erken dönem tasavvuf düşüncesinde mürşîd fikrini anlamak için tâlim ve terbiye şeyhi kavramsallaştırmasında bulunur. Buna göre sûfîler arasında başlangıçta belirgin bir mürşîd-mürid ilişkisi yoktur. Daha çok sûfî akranlığg yahut arkadaşlığı söz konusudur. Dolayısıyla tasavvufi terbiye metodu yatay bir ilişki zemininde karşılıklı bir etkileşime dayanır. Zamanla ise söz konusu bu tâlim şeyhliği, şeyhin otorite kabul edildiği ve mürid ile aralarında belirgin bir ayrışmanın yaşandığı terbiye şeyhliğine dönüşmüştür. bk. Frietz Meier, "Kuşeyrî’nin Tertibü’sSülûku”, çev. Eyüp Kaya, Tasavvuf: İlmi ve Akademik Araştırma Dergisi 4/10, (2003), 365.

47. Kuşeyrî, er-Risâle, 326.

48. Hücvîrî, aynı zamanda Hızır'ın sohbet yoluyla İbrâhim b. Edhem'e mürşitlik ettiğinden ve kendisine ism-i a'zamı öğrettiğinden bahseder: “Çölde dört sene kaldım. İhtiyaç oldukça 
birlikte sohbetin hakikati, insanın ünsiyet bağını, önce Hz. Peygamber daha sonra Allah'a taşımasıdır. Bu anlamda sohbet insanın yetkinlik sürecinin niçin sistematik bir tedrîs ve tâlim sürecinden bağımsız olarak da gerçekleşebileceğini açıklayan bir kavrama dönüşür. Ahlâkî yetkinlikte nazarî eğitimin yerini nübüvvet ${ }^{49}$ ve Allah ile sohbet fikri almaktadır. Bunun anlamı, insanın Hz. Peygamber'in ahlâkını örnek almak suretiyle yetkinleşebileceği iddiasıdır.

\section{Kademeli Başlangıç Fikri: İslâm’a Giriş, Tasavvufa Yöneliş ve Kemâle Ulaşma}

Bazı sûfî başlangıç rivâyetleri Risâle' de birden fazla yerde tekrar edilir. Bununla birlikte aralarında birtakım farklılıklar bulunmaktadır. Bunları şu üç noktada toplayabiliriz: (a) Tasavvuf aracılığıyla İslâm’a giriş. ${ }^{50}$ (b) Müslüman bir kimsenin tasavvufa intisâbı. (c) Sâlikin sülûk sürecinde kemâle ulaşması. Erken dönem tasavvuf literatüründe sûfîlerin nasıl tasavvufa yöneldikleri incelenirken mezkûr üç ayrım dikkate alınmalıdır.

külfetsiz ve sıkıntısız bir şekilde Hakk Teâlâ rızık göndermekte idi. O vakit Hızır Peygamber (a.s.) ile tesadüfen sohbet etmiştim. $\mathrm{O}$, bana Allah'ın en büyük ismini (ism-i a’zamı) öğretmişti. İşte o zaman kalbim, gayr ve mâsivadan, birden boş hale gelmiş ve tamamen temizlenmişti." Hücvîrî, Keş̧ü'l-Mahcûb, 202; Kuşeyrî, er-Risâle, 22.

49. Kuşeyrî, hâl tercümelerine girişte, sûfîlerden "Resulullah'ın ashâbı" olarak bahsediyor. Sahabenin asgari tanımı Peygamber'i bir kez bile olsa görmek yahut onunla beraber olmaktır. Bu anlamı dikkate aldığımızda, sûfîler doğrudan değil belki ama dolaylı olarak peygamberle birlikte olan kişiler anlamına gelmektedir. Buradaki beraberlik fiziksel bir mekân birlikteliği değil, ahlâkî eylemleri taklit anlamında bir sohbet ve birlikteliktir. bk. Kuşeyrî, er-Risâle, 21. 50. Kuşeyrî̀nin farklı bir dinden tasavvuf aracılığıyla İslâmiyet'i benimseyen bir kimsenin ağzından "Eğer Hakk şu tâifelerden birindiyse muhakkak bunlarladır (sûfîlerle) diye kanaat getirmiştim” yönündeki sözleri, ihtida olaylarında niçin tasavvufî yaşamın etkili olduğunu açıklayan bir veçheye sahiptir. Rivâyetin tamamı ise şu şekildedir: "Ebû’l Abbas b. Mesrûk anlatıyor: "Bize bir şeyh gelmişti, muhakemesi iyi, ifadesi tatlı olan bu zât güzel bir üslup ile bize tasavvuf yolunu anlatmaya başladı. Bir kere bize hatırınıza ve kalbinize ne gelirse onu bana söyleyin, dedi. Kalbime bu şeyhin Yahudi olduğu fikri düştü. Bu hâtır kaybolmadı, tersine gittikçe kuvvetlendi. Bu durumu Cerirîye anlattım. Çok zoruna gitti, imkânsız dedi. Ben durumu adama haber vereceğim, dedim. Şeyhe dedim ki: Bize diyorsunuz ki: Kalbinizden her ne geçerse onu bana söyleyiniz. Benim kalbimden senin Yahudi olduğun geçmektedir. Şeyh başını öne eğdi, biraz sonra kaldırdı ve: Doğru, dedi. Allah'tan başka ilâh bulunmadığına ve Muhammed'in Allah'ın Resulü olduğuna şehâdet ediyorum, diyerek şehâdet getirdikten sonra ilave etti: Bütün din ve mezhepleri araştırmıştım. Eğer Hakk şu tâifelerden birindeyse bunlarladır (sûfîlerle) diye kanaat getirmiştim. Bu sebeple denemek için aranıza girmiştim. Siz Hakk üzeresiniz. Adam bundan sonra güzel bir İslâmî hayat yaşadı." Kuşeyrî, er-Risâle, 329-330. 
Marûf Kerhî’nin başlangıç hikâyesi bunun için güzel bir örnek olarak kabul edilebilir. Kuşeyrî, onunla ilgili Risâle'de birbirinden farklı iki rivâyete yer verir. Bunlardan ilki Marûf'un başlangıçta Hıristiyan iken ehl-i beytten biri olan Ali b. Mûsa Rıza vasıtasıyla İslâm’a girişini anlatırken diğeri ise vâizlerin efendisi olarak meşhur İbnü’s-Semmâk (ö. 183/799) adlı bir zâhid-vâizin ${ }^{51}$ sohbetinde işittiği bir söz ile tasavvufî anlamda kemâl sürecinin başlamasıdır. Kuşeyrî’nin ilk rivâyeti şöyledir:

“Marûf'un anne ve babası Hıristiyandı. Marûf daha çocuk iken onu öğretmenlerinden birine teslim etmişlerdi. Öğretmen ona, Allah, üçün üçüncüsüdür, dedikçe O: Hayır, tektir, demiş. Bu sebeple öğretmen onu iyice dövmüş. Marûf da mektepten kaçmıştı. Bunun üzerine anne ve babası, keşke oğlan geri dönse de dini ne olursa olsun, biz de onun kabul ettiği dine girerdik, demeye başlamışlardı. Marûf gitti, Ali b. Mûsa Rıza'nın önünde İslâm’a girdi. Sonra evine döndü. Kapıyı çaldı. İçeriden kim o, diye soruldu. Gelen Marûf'tur diye cevap verdi. Hangi dini benimseyerek geldin, dediler. Hanif dinini diyerek cevap verdi. Bunun üzerine annesi ve babası da Müslüman oldular."52

Kuşeyrî’nin aktardığı bilgide dikkati çeken iki unsur bulunmaktadır. İlki, Marûf el-Kerhî’nin teslisi kabul etmeyişinin bir kerâmet gibi anlatılmasıdır ki bu Risâle'deki diğer ihtida öyküleri ile uyuşmaktadır. Bununla birlikte, Marûf el-Kerhî’nin önceki yaşamında Hıristiyan inancını benimsemiş olması ve bu türden sûfî ihtida öyküleri bazı oryantalist çalışmalarda tasavvufun menşeinin yabancı inanç ve kültürlerle irtibatlandırılması problemini gündeme getirmiştir. ${ }^{53}$ Diğeri ise Marûf el-Kerhî’nin ehl-i beyte mensup biri tarafından İslâmiyet'i benimsemesidir. ${ }^{54}$ Bunun tasavvuf açısından ifade ettiği anlam, ümmîlik ile marifet ve tasavvuf-teşeyyü’ arasındaki ilişkinin mahiyeti problemidir. Kuşeyrî’nin aktardığı ikinci rivâyet şöyledir:

51. Mehmet Demirci, “İbnü’s-Semmâk”, Türkiye Diyanet Vakfi İslâm Ansiklopedisi (Ankara: TDV Yayınları 2000), 21/204-205.

52. Kuşeyrî, er-Risâle, 26.

53. Hikmet Yaman, "İsmi Olmayan Bir Hakikatten Hakikati Olmayan Bir İsme Varan Yolculuk: Oryantalist Çalışmalarda Tasavvufun Menşeine Dair Tartışmalar Üzerine Bir Değerlendirme”, AKADEMİAR Akademik İslâm Araştırmaları Dergisi 1 (2016), 15-48.

54. Hücvîrî, Keşü̉l-Mahcûb, 212-213. 
"Muhammed b. Hüseyin babasından şunu işittiğini nakletmiştir: “Bir defa ölümünden sonra Marûf'u rüyamda görmüş ve Allah sana nasıl muâmele buyurdu? diye sormuştum. Beni affetti, diye cevap verdi. Peki, zühd ve verâya riâyet ettiğin için mi? dedim. Hayır, vâiz İbn Semmâk'ın nasihatını dinlediğim, fakr haline sıkı bir şekilde tutunduğum ve fukarayı sevdiğim için dedi. Marûf'un anlattığına göre İbn Semmâk'ın nasihati şu idi: Bir gün Kûfe'de giderken İbn Semmâk adındaki bir vâizin yanında durdum. İbn Semmâk vaâzı esnasında şöyle demişti: Bir kimse tamamıyla Allah'tan yüz çevirirse, Allah da ondan yüz çevirir. Bir kimse kalbi ile Allah'a yönelirse, Allah da ona rahmeti ile yönelir. Ayrıca bütün yarattıkların yüzlerini de ona yöneltir. Kim ara sıra Allah'a yönelirse, Allah da ona ara sıra merhamet eder. Bu söz kalbime tesir etti. Allah Teâlầya teveccüh ettim. Efendim Ali b. Mûsa Rıza'nın hizmeti hariç bütün meşguliyetimi ve malımı terk ettim. Bu sözü efendim Ali b. Rıza'ya anlatınca: Eğer nasihat almak istersen bu sana kâfidir, dedi." 55

Yukarıdaki anlatıda, Marûf el-Kerhî’nin Müslüman iken zâhid bir vâizin meclisinde işittiği sözün kendisinde yarattığg tesir ile yaşadığ 1 değişim aktarılmaktadır. Söz konusu değişimin, tasavvufa yönelişinin başlangıcı mı yoksa seyr u sülûk içerisinde gerçekleşen kemâl süreci mi olduğu belirsizdir. Bununla birlikte Kuşeyrî’nin Ebû İshak İsferâyînî ile Ebû Osman Mağribî hakkında aktardığı rivâyetlerde yeniden Müslüman olmak ifadesi yer alır. Bu iki sûfî, ruh, ruhun mahlûk oluşu ile Allah tasavvuru konusunda yürütülen ilmî bir tartışma esnasında metafizik bir uyanış yaşarlar ve bu dönüşümü yeniden Müslüman olmak ${ }^{56}$ ile ifade ederler. Marûf el-Kerhî ise yaşadığ1 dönüşümü "Allah Teâlâ’ya teveccüh ettim” sözleriyle ifade eder. Bir kimsenin yüzünü Allah’a yöneltmesinin tasavvuf düşüncesindeki anlamı, kişinin niyet, irade ve eylemlerini insanların övgü ve yergilerinden uzaklaştırarak sadece Allah’a tahsîs etmesi anlamına gelir.

\footnotetext{
55. Kuşeyrî, er-Risâle, 27.

56. "Ebu İshak İsferanî (r.a.)'nin şunu anlattı̆̆gnı duydum: "Bağdat'tan geldiğim zaman Nişabur Camii'nde ruh meselesi üzerine dersler vermekte ve ruhun mahlûk olduğu hususunu izah etmekte idim. Ebû Kasım Nasrabazî bizden uzak bir yerde oturuyor ve sözlerimi Ferrâ’ya: Şu adamın önünde ben yeniden Müslüman oldum, dedi ve bana işaret etti. Nasrabazî ruhun kıdemine inanmakta idi.” Kuşeyrî, er-Risâle, 16; Ebû Osman Mağribî ile ilgili benzer bir rivâyet için bk. Kuşeyrî, er-Risâle, 14.
} 


\section{4. İnsanın Nihai Gayesinin Rızık Değil Marifet Oluşu}

“(Şakîk el-Belhî̀nin) tevbe edip zühde atılışının sebebi şu idi: Şakîk zenginlerden birinin oğluydu. Genç yaşta ticaret için Türk ülkesine gitmişti. Bir puthaneye girdi. Burada putlara hizmetçilik yapan birini gördü. Hizmetçi saçını sakalını traş etmiş, üzerine erguvâni bir elbise giymişti. Şakîk, hizmetçiye: 'Şüphe yok ki senin yaratıcı, hayat sahibi, âlim ve kâdir bir mabûdun var, ona ibadet et, zararı ve faydası olmayan bu putlara ibadet etme' dedi. Hizmetçi ona şu cevabı verdi: 'Eğer durum dediğin gibi ise, o Allah kendi memleketinde sana rızık vermeye kâdir ise bunca sıkıntılara katlanarak ticaret için buraya kadar neden geldiniz?' Bu söz üzerine uyanan Şakîk zühd yolunu tuttu." ${ }^{\text {57 }}$

Kuşeyrî̀nin başlangıç hikâyesine yer verdiği sûfîlerden bir diğeri tevekkül-kesb ilişkisine dair ortaya koyduğu yaklaşımla tanınan Şakîk el-Belhî' dir. ${ }^{58}$ Kesb hakkındaki yorumları sebebiyle İmam Muhammed'in Kitâbüll-kesb ile Muhâsibî (ö. 243/857)'nin el-Mekâsib adlı eserlerine doğrudan muhatap olmuştur. İnsanın özgürlüğü sorununun bir uzantısı olan tevekkül-kesb problemine göre, rizık Allah tarafından mı yaratılmaktadır yoksa insanın ancak peşinden koşmak suretiyle elde edebileceği bir şey midir? İlki doğruysa, insanın rızık endişesi ile çalışıp çabalaması paradoksal bir durumu ortaya çıkarmaz mı? Şayet rızık için çabalamazsak bu sefer aile gibi sorumluluklarımızın durumu ne olacak? Kuşeyrî, sûfî portrelerde Şakîk el-Belhî’nin üç farklı başlangıç hikâyesine söz konusu problemi taşır. Ayrıca Risâle'nin sefer ahkâmı başlıklı bölümünde sûfîlerin rızık endişesi ile ilgili yaklaşımını gösteren pek çok menkıbeye atıfta bulunur. Bu anlatıların odak noktası, günümüzdeki ulaşım şartlarının konforundan uzak meşakkatli bir seyahat sürecinde, sûfîlerin rızkın

57. Kuşeyrî, er-Risâle, 36. Bir diğer varyantı şu şekildedir: "Şakîk'in zühd hayatına atılışının sebebi olarak şu hadiseden de bahsedilir: Bir kıtlık senesi oynayıp eğelenen şen ve şakrak bir köle gördü. Bütün halk geçim derdinde idi. Şakîk köleye: Bu ne neşe böyle? Halkın kuraklıktan ve kıtlıktan çektikleri sıkıntıyı görmüyor musun? dedi. Hizmetçi: Bundan bana ne? Efendimin hususi bir çiftliği var, muhtaç olduğumuz her şeyi buradan sağlıyorum, dedi. Bunun üzerine Şakîk intibâha geldi ve: "Bu hizmetçinin beyinin bir köyü var, efendi fakir bir mahlûk iken köle ona güvenerek rızık kaygısı çekmiyor. Mevlâsı zengin olan bir Müslümanın rızık kaygısı çekmesi nasıl uygun olur, dedi.”a.mlf., er-Risâle, 36. Bu rivâyetin benzer bir varyantı için bk. Hücvîrî, Keş̧ü'l-Mahcûb, 210-211.

58. Şakîk-i Belhînnin hayatı ve tasavvufî tavrını etraflıca yer veren bir yazı için bk. M. Nedim Tan, “Tasavvuf Istılahlarının Teşekkül Dönemi Açısından Şakîk-i Belhî’nin Âdâbü’l-İbâdât'ı”, Marmara Üniversitesi İlahiyat Fakültesi Dergisi 45 (2013), 159-173. 
Allah'tan geleceğine dair duydukları sarsılmaz inançtır. Bu nedenle pek çok mutasavvıf, yolculuk esnasında yanlarına hiçbir yiyecek almazlar. Bu noktada Kuşeyrî̀nin benimsediği yaklaşım insanın nihai gayesinin rızık olmadığı ve insanın Allah dışındaki sebeplere tevessül etmesinin tevhîd ilkesiyle bağdaşmayacağı yönündedir. Dolayısıyla Şakîk el-Belhînnin tasavvuf yoluna girişinin başlangıcı rızkını Allah dışındaki bir yoldan aramak suretiyle, unuttuğu varoluş gayesini putlara tapan bir insan tarafından kendisine hatırlatılmasıyla gerçekleşir. Onun söz konusu metafizik uyanışı kendi dışındaki bir insanı işitmek/dinlemek suretiyle yani semâ kanalıyla gerçekleşir. İnsanın duyular aracılığıyla nihai gayesini hatırlaması Zünnûn el-Mısrînin başlangıç hikâyesinde de yer almaktadır:

“Bir kere bir kasabaya gitmek üzere Mısır'dan ayrılmak istemiştim. Sahrada yolculuk yaparken bir yerde uyumuştum. Gözlerimi açınca, altında uyuduğum ağaçta bulunan bir yuvadan kör bir tarla kuşunun düştüğünü görmüsstüm. Kuş düşer düşmez yer yarıldı, içinden biri susam, diğeri su dolu iki kavanoz çıtı. Kuş, bundan yemeye, ondan içmeye başladı. Bunu görünce bu kadarı bana kâfidir, dedim. Hemen tevbe ettim. Tevbem kabul edilene kadar Kerîm olan Allah'ın kapısindan ayrilmadım. ${ }^{59}$

İnsanın nihai gayesinin rızık olmadığını ve rızkın gerçek sebebinin Allah olduğunu göstermek için Kuşeyrî̀nin verdiği 'kör bir tarla kuşu' örneği son derece anlamlıdır. Zira kuşun kör olarak tavsif edilmesinin nedeni kuşun rızkını elde etmek için kesb yolunun kendisine kapalı olduğunu vurgulamaktır. Buna rağmen tarla kuşu yere düşer düşmez olağanüstü bir şekilde yer yarılmakta, içleri susam ve su dolu iki kavanoz ile karşılaşmaktadır. Zünnûn el-Mısrînnin görme duyusuyla şâhit olduğu bu olay, ona insanın rızkı ile kesb arasında kurduğu nedensellik bağının yanlışlığını idrak etmesini sağlar. Görüldüğü üzere gerek Şakîk el-Belhî gerekse Zünnûn el-Mısrî sahip oldukları duyular aracılığıyla, (biri işitme diğeri ise görme sayesinde) kemâl süreçleri başlar. Bu iki sûfînin öyküsünde dikkati çeken bir diğer husus tasavvufa yönelişlerini ifade etmek için tercih ettikleri ifadelerdir. Şakîk el-Belhî, tevbe ve zühd terimlerini kullanırken; Zünnûn el-Mısrî ise sadece tevbeye atıfta bulunmaktadır. Kuşeyrî̀nin düşüncesinde tevbe dört farklı anlamda kullanılır: (a)

59. Kuşeyrî, er-Risâle, 24, 409. 
Tevbenin gerekçesi. Bu konuda Kuşeyrî, insanın ya uhrevî bir cezadan sakınmak (tevbe), yahut uhrevî bir ödüle kavuşmak (inâbe) ya da sadece Allah için (evbe) olmak üzere üç gerekçe zikreder. Tevbenin hakikati, sadece Allah için yapılandır. ${ }^{60}$ (b) Tevbe ile insanların yetkinlik dereceleri arasında irtibat. ${ }^{61}$ (c) Erdemli eylemlerden doğabilecek kibirden tevbe etmek. ${ }^{62}$ (d) Tevbenin yönü. Bu konuda Kuşeyrî, tevbenin esasında insandan Allah'a değil de Allah'tan insana doğru gerçekleştiğine dair aktarımlarda bulunur. ${ }^{63}$ Şakîk el-Belhî ile Zünnûn el-Mısrî̀nin tevbelerinde uhrevi bir ceza yahut ödül vurgusu yerine Allah'a bir atıf vardır. Nitekim Kuşeyrî tevbe ile Allah tasavvuru arasındaki kuvvetli ilişkiyi göstermeyi amaçlar. Bu meyanda portreler dışında biri Mecûsî ${ }^{64}$ diğeri kâfir ${ }^{65}$ olan iki kişinin İslâmiyet'in âdil ve merhametli Tanrı tasavvuru aracıllı̆ıyla Müslüman oluşlarını aktarır.

\section{5. İnsanın Kemâl Sürecinin Başlangıcında Duyuların İşlevi: İşitmek ve Görmek}

Kuşeyrî̀nin sûfî portrelerde yer verdiği başlangıç hikâyelerinde dikkati çeken bir diğer husus ise insanın duyuları vasıtasıyla gayesini idrak

60. Kuşeyrî, er-Risâle, 129-130.

61. Kuşeyrî, er-Risâle, 130.

62. Kuşeyrî, er-Risâle, 130-131.

63. Kuşeyrî, er-Risâle, 132-133.

64. "Naklederler ki: Bir Mecûsî, İbrâhim'e (a.s.) misafir olmak istedi. Hz. İbrâhim Mecûsîye şayet İslâm’a girersen misafir ederim, dedi. Mecûsî ben Müslüman olursam senin bana yaptı̆̆gin ihsânın ne faydası olur ki? dedi ve savuşup gitti. Allah Teâlâ İbrâhim'e (a.s.) şunu vahy etti: Ey İbrâhim! Bir kulum dinini değiştirmiyor diye neden ona yemek yedirmiyorsun? Halbuki yetmiş senedir kâfir olduğu halde biz o zâta rızkını veriyoruz. Bir gece de onu sen misafir etseydin, bunun sana ne zararı olacaktı? Bu hitâbı duyan Hz. İbrâhim (a.s.) Mecûsînnin peşine düştü. Onu buldu ve misafir etti. Mecûsî ona: Görüşünüzü ve davranışınızı değiştirmenizin sebebi nedir? diye sordu. O da durumu anlattı. Bunun üzerine Mecûsî Hz. İbrâhim’e sordu: Gerçekten Allah bana böyle mi muamele ediyor? dedi, sonra: Bana İslâm’ı anlatınız dedi ve Müslüman oldu." Kuşeyrî, er-Risâle, 170-171, 262.

65. "Derler ki İbn Mübârek bir kere iri yarı bir kâfirle cenk ediyordu. Kâfirin ibadet vakti geldi. İbn Mübârek'ten ibadet için mehil istedi. $O$ da istenen mehli verdi. Kâfir güneşe secde edince İbn Mübârek kılıcı ile başını kesmek istedi. Sema ve hâtiften bir ses işitti: "Ahde vefa ediniz. Şüphesiz kişi verdiği sözden mesuldür” (el-İsrâ17/34) diyordu. Bunun üzerine İbn Mübârek niyetinden vazgeçti. Mecûsî ibadetini bitirince: Yapmayı düşündüğün şeyi icra etmekten neden vazgeçtin? diye sordu. O da işittiği sesi anlattı. Bunun üzerine Mecûsî dedi ki: Ne iyi Rabb, düşmanı için dostunu tekdir ediyor. Sonra derhal Müslüman oldu ve güzel bir İslâm hayatı yaşadı." Kuşeyrî, er-Risâle, 171. 
etmesi ve böylece metafizik bir uyanış yaşamasıdır. ${ }^{66}$ Erken dönem tasavvuf literatüründe duyular hakkında üç farklı yaklaşım bulunur: (a) Duyuların ıslâhı/terbiyesi (arındırılması) (b) Duyular aracılı̆̆ıyla idrak (c) Hakikatin beş duyu aracılığıyla tasviri. ${ }^{67}$ Duyuların arındırılması ile kast edilen şey gözün, kulağın, dilin vb. duyuların haram olan durumlardan muhafaza edilmesidir. Böylece duyular dış dünya ile kalp arasında ahlâkî bir süzgeç işlevi görür.

Duyuların idraki ise tasavvufun özgün yaklaşımını yansıtır. Sûfîlere göre duyuların iki işlevi vardır: (a) Duyumsamak. Gözün eşyayı görmesi, kulağın fiziksel sesleri işitmesi gibi. (b) Allah ile akleden insanın duyularının idraki. Allah ile akletmenin neticesinde duyular ile idrak arasında doğrudan bir köprü oluşur. Böylece göz gördüğü her şeyde Allah'ın fiil ve kudretini görür iken; kulak işittiği her seste Allah'ın sesini duyar hale gelir. Bu konuya değinen ilk sûfî düşünürlerden biri de Hâris el-Muhâsibî̀dir. Muhâsibî’nin el-Akl risâlesinde vazettiği kademeli akıl teorisine göre garîze, fehm, basiret ve kâmil olmak üzere aklın dört yetkinlik derecesi bulunmaktadır. Bu akıl dereceleri arasında fehm ile basiret arasındaki en önemli fark iman olgusudur. Muhâsibînnin temel iddiası iman etmiş bir kimsenin duyularının ikili bir işleve sahip olduğudur. Bunun anlamı duyuların birincil fonksiyonları haricinde idrak etme işlevi kazanmalarıdır. $\mathrm{Bu}$ çerçevede fehm akla sahip kimseler için şu âyeti örnek olarak verir: "Onların öyle kalpleri vardır ki, onlarla anlamazlar ve öyle gözleri vardır ki, onlarla görmezler ve öyle kulakları vardır ki, onlarla işitmezler.” (elA'râf 7/179). Hâlbuki iman etmiş, basiret akla sahip kimselerin duyuları aynı zamanda akletmektedir ki bu minval üzere işitme duyusu hakkında "Allah ile akleden bir kulak" (أذن عقلت عن الله تعالى) ifadesini kullanır. ${ }^{68}$

\footnotetext{
66. Yakın bir zamanda tasavvuf düşüncesinde duyuların işlevi ile ilgili kaleme alınmış ufuk açıcı bir yazı için bk. Ekrem Demirli, "Sarih Akıl ile Sahih Fıtrat Arasında Selim Duyular: İnsanın Hakikat Arayışında Duyuların Yeri”, Sabahülkesi (Erişim 12 Ocak 2021).

67. Kuşeyrî, tasavvufi ıstılahlar bölümünde yer verdiği “Zevk-Şirb” maddesinde, insanın hakikat ile ilişkisini, zevk (tatma), şirb (içme) ve reyy (kanma) olmak üzere üç şekilde ele alır. Böylece bilginin kesinlik derecelerini yeme-içme yani tat alma duyusundan hareketle tasvir eder. Öte yandan, zevk sahibinin yarı sarhoş, şirb sahibinin tam mest, reyy sahibinin ise sahv yani ayıklık halinde olduğunu söylemesi, onun sahv çizgisinde bir insan tanımı ortaya koyduğunu gösterir. Kuşeyrî’ye göre aşkı kuvvetli olanın şirbi devamlı olur; şirbi devamlı olanın durumu ise ayıklık olur yani sekri doğurmaz. bk. Kuşeyrî, er-Risâle, 108.

68. Hâris b. Esed Muhâsibî, Şerefü>l-Akl ve Mâhiyyetuhu, thk. Mustafa Abdülkadir Ata (Beyrut: Dârü'l-Kütübi'l-İlmiyye, 1986/1406), 26, 30-31.
} 
Bu konuda Kuşeyrî, sûfî portrelerde daha önce gördüğümüz İbrâhim b. Edhem, Şakîk el-Belhî ve Zünnûn el-Mısrî̀ye ilaveten Fudayl b. İyaz ile Davud et-Tâî'nin başlangıç hikâyesine atıfta bulunur:

"Fudayl, başlangıçta Serahs ile Ebiver arasında yol kesen bir şakî idi. Tevbe edip kendisini düzeltmesinin sebebi şu idi: Bir cariyeye âşık olmuştu. Cariyeyi görmek için duvara tırmanırken bir hâfızın: “Mü’minlerin kalplerinin Allah’ın zikri karşısında huşû’ duymaları zamanı gelmedi mi? (Hadid: 57/16) meâlindeki âyeti okuduğunu duydu ve birden: "O an geldi Ya Rabb" diyerek derhal geri döndü. Yolu bir harabeye uğradı. Geceyi burada geçirirken yakında bulunan bir insan topluluğundan birinin arkadaşlarına: "Buradan kalkıp gidelim" diğerlerinin ise "Burada sabahı edelim. Çünkü gecenin bir saatinde Fudayl bizim yolumuzu keser" dediğini işitti. Fudayl bu hadise üzerine bir kere daha tevbe etti. Gruba güvenle gidebileceklerini söyledi. Sonra Mekke’ye gelerek ölene kadar burada mücâvir hayatı yaşadı."69

“Bağdat'ta fukaradan birinin şöyle dediğini işittim: "Davud Tâînin zühd sebebi şu beyti okuyarak, ölüsüne ağlayan bir kadını dinlemiş olması idi: "Şimdi o yanakların hangisi çürümede ve o gözlerinden hangisi akmada." 70

Görüldüğü üzere her iki sûfînin de yetkinlik süreci, işitme yani semâ yoluyla gerçekleşmektedir. ${ }^{71}$ Öte yandan Nefehâtü’l-Üns'te Fudayl b. İyâz zengin ticaret kervanlarının önünü kesip, el koyduğu malları fakir ve yoksullara dağıtan, oruç tutan ve namaz kılan korkusuz bir eşkıya olarak

69. Kuşeyrî, er-Risâle, 25. Kuşeyrî, Dâvud et-Tâînnin bir başka başlangıç hikâyesine daha atıfta bulunur: “Üstad Ebû Ali Dekkâk (r.a)'tan duydum: “Davud Tâînin zühd sebebi şu idi: Bağdat'ta gezmek adeti idi. Bir gün yolda giderken, Emir Hamid Tûsînin önünden gidip yol açan polislerin kendisini yolun kenarına ittiklerini gördü. Sağına soluna bakınınca Hamid’i gördü. Bunun üzerine bir dünya ki; orada Hamid seni geçer, yuh ona dedi. Sonra evinin bir köşesine çekildi. Bütün vaktini ibadete ve mücâhedeye verdi.” Kuşeyrî, er-Risâle, 34 .

70. Kuşeyrî, er-Risâle, 34 .

71. Kuşeyrî, Şiblî (ö. 334/945) ve Havvâs'ın Hayru'n-Nessâc'ın meclisinde tevbe ettiği bilgisini aktarır. Fakat bu bölümde Şiblî ve Havvâs'ın başlangıç hikâyelerine yer vermez. Daha sonra Şiblî’nin hâl tercümesi için ayırdığı bölümde bu konuya dâir şu kısa alıntıya yer verir: "Hayru’nNessâc'ın meclisinde ilk defa tevbe edip halini düzelttikten sonra Demavend'e geldi: Biliyorsunuz memleketinizin vâlisi idim. Şimdi bu vazifeyi bırakıyorum, hakkınızı helal edin, dedi. Başlangıçta haddinden fazla mücâhede ve riyâzetle uğraştı.” Kuşeyrî, er-Risâle, 71. Dolayısıyla söz konusu iki sûfînin tasavvufa yönelmelerinin esas sebebi Hayru'n-Nessâc'ın dersinde işittikleri bir söz yahut konuşma olabilir. bk. Kuşeyrî, er-Risâle, 69. 
resmedilir. ${ }^{72}$ Onun hakkındaki bu bilgi işitme düzeyinde Allah'tan gelen vâridi niçin bazı insanlarda aydınlanmaya sebebiyet verirken diğerlerinde aynı etkiyi göstermediğini izah edebilir. Nitekim bu anlatılara göre Fudayl b. İyâz, tevbe edip tasavvufa yönelmeden önce de muhtaçları gözeten ve ibadet eden bir kimse olarak tasvir edilmektedir. Tasavvuf düşüncesine göre ihlâs üzere yapılan ameller insanda marifeti açığa çıkarabilir. Böylece, insanda işittiği bir ses yahut gördüğü herhangi bir manzara metafizik uyanışa (intibâh) sebep olabilir. ${ }^{73}$

İlk dönemde sûfîler semâ terimini "sûfînin kendisine gelen vâridi işitmesi ve işittiğini kalbe aktarması" "74 anlamında kullanırlar. Buna göre Allah'tan gelen vâridin işitilmesi neticesinde kalpte birtakım hâller gerçekleşebilir. Bu hâller kişinin yetkinlik mertebesine göre değişik şekillerde ortaya çıkar. Hüzün, özlem, yakınlık-uzaklık, sevinç, bayılma gibi haller buna örnek olarak verilebilir. Kuşeyrî, Risâle'de semâ kavramının bu ilk anlamına karşılık gelmek üzere hâl ile semâ ifadesini kullanır. O, hâl ile semâyı "İtâb, hitâb, vuslât, hicrân, yakınlık, uzaklık, elden çıkana üzülme, elde edilecek olana karşı hararetle istek duyma, ahde vefa etme, vaadi tasdik etme, ahdi bozma, hüzün, özlem, ayrılık korkusu, vuslât sevinci ve terk edilme endişesi gibi, vâridatı hatırlamak suretiyle düşünme” şeklinde tanımlar. ${ }^{75}$ Fakat işitilen sözün içeriği ile dinleyen kimsenin yetkinlik mertebesi semânın tesir kuvvetini ve kalpte ortaya çıkan hâlleri belirler. ${ }^{76}$ Sûfi müellifler bu anlamda işitilen sözleri de kendi içinde Kur'ân, şiir, nağme, menkıbe gibi kademeli bir şekilde ele alarak, en üstün üstün

72. Câmii, Nefahâtü'l-Üns, 38, 92.

73. Sûfî portreler dişında Risâle'de geçen benzer bir rivâyet için bk. "Demirci Ebû Hafs Nişâbûrînin sanatını terk edişi ile ilgili sülûkunun başlangıcındaki şu menkıbe çok meşhurdur: Ebû Hafs dükkanında çalışırken bir hâfızın Kur'ân'dan bir âyet okuduğunu işitir ve kalbine gelen vârit sebebiyle hissini kaybederek kendinden geçer. Daha sonra elini ateşe sokmak suretiyle ocaktaki kızgın demiri eli ile çıkartır. Bu durumu gören bir müridi ona şöyle der: Üstad, bu ne hâl! Bunun üzerine Ebû Hafs kendisinden zuhûr eden kerametin farkına vararak, sanatını terk eder ve dükkânından çıkıp gider.” Kuşeyrî, er-Risâle, 105.

74. Semih Ceyhan, "Semâ", Türkiye Diyanet Vakfi İslâm Ansiklopedisi (İstanbul: TDV Yayınları, 2009), 9/455-457.

75. Kuşeyrî, er-Risâle, 426-427; Serrâc, el-Lüma', 320.

76. Kuşeyrî, Risâle'de semâ bahsinde işittikleri sesler nedeniyle yaşamını yitiren sûfîlere yer verir. Allah’tan gelen hitâbın doğrudan işitilmesi karşısında bu sûfilerin cismânî bedenleri adeta parçalanır. Kuşeyri, er-Risâle, 398-399. "Ebû Ali Ruzbârî diyor ki: "Bir köşkün yanından geçmiş, güzel yüzlü bir gencin yerde serili bir vaziyette yattığını, etrafında halkın toplanmaya başladı̆̆ını görmüş ve gencin halini sormuştum. Dediler ki: Genç buradan geçerken, köşkteki bir cariyenin şu şarkıyı söylediğini işitti: Seni görmeye tamah eden bir kulun himmeti ve niyeti 
sözün Allah'ın kelâmı olduğunu ifade etmişlerdir. Öte yandan Hücvîrî, Keşfü'l-Mahcûb'ta semâ bahsine ilmin vasıtaları olması bakımından işitme, görme, tatma, koklama ve dokunma duyularına atıfta bulunarak başlar ve işitmenin diğer duyulara nazaran üstün olduğunu iddia eder. Bunun temel nedeni, vahye muhatap olan ilk duyunun işitme olmasının yanı sıra bütün dinî sorumlulukların zemini olması nedeniyledir. ${ }^{77}$ Bununla birlikte sûfiler insan doğasının Kur'ân'ı dinlemeye yatkın bir surette yaratıldığını düşünürler. Daha açık ifade etmek gerekirse insan doğası gereği Allah'ın kelâmına ihtiyaç hisseder ve ona yönelir. Bu insanın tabiatında mündemiç ilâhî bir ilkedir. ${ }^{78}$ Risâle' de sûfîlere ait başlangıç hikâyelerinin büyük bir kısmı ise işitilen ilâhî ya da beşerî bir sözün etkisiyle başlamaktadır. Dolayısıyla bu sözler Allah'tan insana gönderilen vârid ${ }^{79}$ anlamında semâ kapsamında değerlendirilmelidir. Kuşeyrî Risâle'de semâ terimini sadece fiziksel bir işitme, nağmeli ve besteli söz yahut çalgı anlamında değil ${ }^{80}$ aksine insanın nihai gayesini oluşturan Allah'ın hatırlaması şeklinde değerlendirir. ${ }^{81}$ Bu konuda Risâle'de Cüneyd-i Bağdâdî’nin semâ ile elest ahdi arasında kurduğu şu rivâyete yer verir:

"Cüneyd'e sorulmuş: Sakin sakin duran bir kimse sema dinlediği zaman neden sallanmaya başlıyor? Şöyle demiş: Allah Teâlâ ezel ve elest bezminde ilk misakta rûhlara: Ben sizin Rabbiniz değil miyim? diye hitâp

ne kadar yücedir! Seni göreni görmesi için bir göz için kâfi değil midir? Bunu dinleyen genç bir çı̆̆lık attı ve öldü.” Kuşeyrî, er-Risâle, 377-378.

77. Hücvîrî, Keşü̉l-Mahcûb, 543-545.

78. “Kur'ân'ın mucizelerinden biri, onu dinlemekten ve okumaktan (insani) tabiatın nefret etmemesi ve hoşnutsuz olmamasıdır. Bunun sebebi onda muazzam bir rikkatin (inceliğin ve dokunaklı olma halinin) mevcut olmasıdır. O derecedeki Kureyş kâfirleri bile gece gizlice gelir, Resülullâh (s.a.v) namazda iken okuduğu şeyi dinler, taaccüp ve hayretlerini belli ederlerdi.” Hücvîrî, Keşü̉l-Mahcûb, 545. İnsan tabiatı ile Kur'ân arasındaki doğal irtibatı vurgulayan bir diğer sûfî müellif Hâris b. Esed el-Muhâsibî'dir. bk. Hâris b. Esed el-Muhâsibî, el-Akl ve Fehmu'lKurân, thk. Hüseyin Kuvvetli (b.y.: Dârü'l-Fikr, 1971), 286-287.

79. Bir tasavvuf terimi olarak vârid (ç. vâridât) "Kulun kasdı olmaksızın gaybten (Hak’tan) kalbe gelen manalar. Allah'tan gelen vâride (ilhama, feyze) vârid-i Hak, ilimden (şeriattan) gelen vâride vârid-i ilim denir. Bazı vâridler neşe ve sevinç, bazıları hüzün ve sıkıntı tesiri yapar.” Süleyman Uludağ, Tasavvuf Terimleri Sözlüğü (İstanbul: Kabalcı Yayınevi, 2001), 367.

80. Kuşeyrî kendisinin üstadından semâ için rûhsat istediğini ve fakat daha sonra bunu verdiğini verirken de esas semânın kalp ile yapılması gerektiğine dâir aktarımı mevcut. Bu durum semânın açık bir şekilde ruhsat verilmediğini yahut açıktan yapılmasının hoş karşılanmadığını göstermektedir. bk. Kuşeyrî, er-Risâle, 377.

81. “Zünnûn şöyle demişti: Hakk'tan gelen ve kalpleri Hakk’a doğru harekete geçiren bir vârid ve sâik. Kim semâyı Hakk ile dinlerse hakikat mertebesine çıkar. Kim nefsâniyet ile dinlerse zındıklık derecesine düşer.” Kuşeyrî, er-Risâle, 369. 
etmiş. Rûhlar da: Evet, öyle demişlerdi. (Araf, 7/172) İşte o zaman bu kelâmın işitilmesinden (semâ) hâsıl olan şevk ve lezzet rûhlara yerleşti. Sema dinledikleri zaman onu hatırlar ve harekete geçerler." 82

\section{Eylemden Bilgiye Ümmîlikten Marifete Geçiş}

Sûfî portrelerde yer alan başlangıç hikâyelerinin bir kısmı, bilgi-eylem ilişkisine atıfta bulunur. Buna göre saf ve hâlisane bir niyetle yapılan bir amel, insanda metafizik uyanışı tetiklemektedir. Bu çerçevede Kuşeyrî, Bişr Hâfî ile Mansûr b. Ammâr'ın büyük bir benzerlik içeren tasavvufa yöneliş hikâyelerine yer verir. Her iki sûfî yolda yürürken üzerinde Allah’ın ismi yazılı bir kâğıda tesadüf ederler. Biri kâğıdı yerden alır, yanında bulunan miski çıkarır ve üzerine sürer, daha sonra da bir duvar boşluğuna yerleştirir. Diğer sûfî ise koyacak bir yer bulamadığı için yutmayı tercih eder. Bunun neticesinde her iki sûfî gördükleri rüyada Allah'ın kendilerine memnuniyet içerikli hitâbına mazhar olurlar. Bu olay her ikisinin kemâl sürecinin başlangıcını oluşturur. Bununla birlikte Bişr b. Hâfî ve Mansûr b. Ammâr tasavvufa yönelişlerini tevbe ile ifade ederler. Birbiriyle benzerlik arz eden iki porte aşă̆ıdaki gibidir:

“Tevbe etmesinin sebebi şu idi: Yolda halk tarafından ayaklar altında çiğnenen ve üzerinde Aziz ve Celil olan Allah'ın isminin yazılı olduğu bir kâğıda tesadüf etti. Kâğıdı yerden aldı ve bir dirheme satın alıp yanında bulundurduğu misk ile kokulandırdı ve bir duvar yarı̆̆ına koydu. Bu hâdise üzerine uyuyan bir insanın rüyada gördüğü bir şekilde birisinin kendisine şöyle dediğini işitti: Ey Bişr! Sen ismimi güzel bir koku ile kokulandırdın. Hiç şüphen olmasın ki ben de senin ismini dünya ve âhirette hoş bir koku ile kokulandıracağım." ${ }^{\text {"3 }}$

82. Kuşeyrî, er-Risâle, 369. Kelâbâzî, semâ ile elest bezmi arasındaki irtibata Ebû Muhammed Rûveym'den rivâyetle şu şekilde yer verir: “Sûfîler ilk zikir olan: 'Rabbınız değil miyim' (elA’râf 7/172), ilâhî hitâbını işittikleri zaman bu hitab onların ruhlarının derinliklerinde gömülüp kalmıştı. Nitekim bu hitâbın akıllardaki mevcudiyeti de gizli ve saklı bir halde kalmıştır. İnsanlar semâ'ı dinledikleri zaman, sırlarında saklı olan o ilâhî hitap açığa çıkar ve onlar da bunu dinleyerek coşarlar. Nitekim akıllarında gizli bulunan şeyi Hakk haber verdiği zaman onu hemen tasdik ediverirler." Muhammed b. İbrahîm Kelâbâzî, Ta’arruf: Doğuş Devrinde Tasavvuf (İstanbul: Dergâh Yayınları, 2016), 246.

83. Kuşeyrî, er-Risâle, 30. Hücvîrî’de Bişr’in başlangıç hikâyesinde farklı olarak şu cümleler ile başlamaktadır: "Bir gün sarhoşluktan sendeleye sendeleye yürürken yolda bir kâğıt parçası buldu. Onu hürmetle eline aldı. Üzerinde ‘Bismillahirrahmanirrahim’ yazılı idi.” bk. Hücvîrî, Keşü̈l-Mahcûb, 203. 
"Derler ki: Tevbe etmesinin sebebi şu idi: Bir kere yolda giderken üzerinde ‘Bismillâhirrahmânirrahim' yazılı olan bir kâğıt bulmuş, bu kâğıdı koyacak uygun bir yer bulamadığı için yutmuştu. Bunun üzerine rüyasında birinin: 'O kâğıda hürmet ettiğin için Allah senin üzerine kapalı olan hikmet kapısını açtı’ dediğini işitti." ${ }^{84}$

Bilgi-eylem ilişkisine atıfta bulunulan bir başka anlatı Dâvûd et-Tâîye aittir. Ebû Hanife'nin verdiği derslerden birinde amele yaptığı güçlü vurgu onun kemâl sürecinin başlangıcı kabul edilir. Böylece kendisine bir daha cedel ve tartışma içerisine girmeyeceğine dair bir söz verir. Dâvûd et-Tâî kendine verdiği sözü tutmakta ne kadar zorlandığını şu sözleriyle ifade eder: "Bir meseleye cevap vermek durumunda kaldiğım olurdu. Ben o mesele hakkında konuşmaya, susuz kalmış bir insanın soğuk suya duyduğu istekten daha şiddetli bir arzu duyar, fakat yine de o konuda konuşmazdım." Tasavvufi düşüncede cedel ve tartışma kibre sebebiyet vermesi ve doğru düşünmeyi engellediği için negatif bir anlama sahiptir. Bu nedenle Ebû Hanife'nin ders meclisine devam etmekte olan Dâvûd et-Tâî, cedelden uzak durmak ile ilgili bilgisini tatbik etmek için kendini zorlar. Bunun neticesinde ise ahlâkî yetkinliğe ulaştı̆̆ını ifade eder. Bununla birlikte Dâvûd et-Tâî, tasavvufa başlangıcını zühd terimi ile ifade etmeyi tercih eder. Kuşeyrî’nin aktardığı rivâyet şöyledir:

"Derler ki onun zühd hayatına atılmasının sebebi şu idi: Ebû Hanife'nin (r.a.) meclislerine devam ederdi. Bir gün İmâm-1 Azam dedi ki: 'Ey Dâvûd! Biz alet ve edevâtı (şer'î ilimleri) muhkem hale getirdik.' Dâvûd sordu: 'Geriye ne kaldı?' Ebû Hanife cevap verdi: 'Onunla amel etmek.' Dâvûd diyor ki: 'Ebû Hanife'nin bu ikazı üzerine uzlete çekilmem hususunda nefsim benimle çekişmeye başladı. Nefsime hiçbir meselede konuşmamak şartı ile Ebû Hanife'nin meclislerine devam etmedikçe seni uzlete çekmem' dedim. Kimse ile bir şey konuşmamak şartıyla bu meclislere devam ettim. Bir meseleye cevap vermek durumunda kaldı̆̆ım olurdu. Ben o mesele hakkında konuşmayan, susuz kalmış bir insanın soğuk suya duyduğu istekten

84. Kuşeyrî, er-Risâle, 48. Mansûr b. Ammâr'ın tasavvufa yönelişi, rüyasında kendisine hikmet kapısının açılması şeklinde ifade edilmesi dikkat çekicidir. Erken dönemde bazı sûfî müelliflerin metinlerinde hikmet ve hakîm, tasavvufî bilgi ve mürşîd için kullanılmaktadır. Cüneyd-i Bağdâdî’nin Amr b. Osman el-Mekkî̀ye yazdığ̣ mektupta yer verdiği âlim-hâkim arasındaki diyalog bu kullanım için örnek olarak verilebilir. bk. Cüneyd-i Bağdâdî, Resâilü’l-Cüneyd, thk. Ali Hasan Abdulkadir (Kâhire: Darü'l-Kütübi'l-Mısriyye, 1988) 8-11. 
daha şiddetli bir arzu duyar, fakat yine de o konuda konuşmazdım.

Bundan sonra Dâvûd et-Tâ̂̂’nin durumu bilinen şekli aldı." ${ }^{85}$

Tasavvuf literatüründe eylem (amel) terimine şu iki içerik yüklenir: Kalbin amelleri ve amellerde süreklilik. Kalbin amelleri ile kastedilen kıskançlık, kibir, öfke yahut şefkat, tevazu, gibi ahlâkî eylemlerin hisle irtibatlı kökleridir. Sûfîler kalbin amellerini ihlâs ve riyâ olmak üzere iki kavram etrafında değerlendirirler. Buna göre, insan ahlâkî eylemlerini sadece Allah'ın rıza ve mahabbeti için gerçekleştiriyorsa ihlâs; buna mukabil Allah dışındaki herhangi bir şey için-örneğin insanların övgüsünü kazanmak yahut yermesinden kaçınmak gibi-gerçekleştiriyorsa riyâ açı̆̆a çıkar. ${ }^{86}$ İkinci husus ise amellerde süreklilik ilkesidir. Bu noktada sûfîler, insanın kemâl sürecinin sadece ibadetler ile sınırlı olmadı̆̆ını aksine insanın nefes alıp verdiği her zaman diliminde, Allah'ın huzurundaymış gibi düşünmesi ve davranması gerektiğini söyler.

Kuşeyrî amelin devamlılığı ile ilgili Risâle’de Marûf el-Kerhî’nin şu rivâyetini aktarır: "Dâvûd et-Tâînin sohbetinde bulunanlardan biri bana sakın ameli terk etmeyesin. Çünkü amel seni Mevlâ’nın rızasına yaklaştırır, dedi. Ben de amelden kastın nedir? diye sordum. Bana şu cevabı verdi: Rabbine itaat halinde dâim olmak, Müslümanlara hizmet ve nasihatta bulunmak." ${ }^{87}$ Dolayısıyla Bişr b. Hâfî ile Mansûr b. Ammâr'ın sergiledikleri davranış, kalbin amelleri bakımından ihlâsı ifade ederken; üzerinde Allah'ın ismi yazılı olan bir kâğıda gösterdikleri hürmet eylemi, onların ibadeti nasıl gündelik hayata taşıdıklarını gösteren bir örnektir. ${ }^{88}$

85. Kuşeyrî, er-Risâle, 34 .

86. Erken dönem tasavvuf literatüründe kalbin amelleri meselesine eğilen iki sûfî müellif olarak Hâris b. Esed el-Muhâsibî ile Cüneyd-i Bağdâdî zikredilebilir. Muhâsibî ihlâs ve riya; Cüneyd-i Bağdâdi ise ihlâs, sıdk ve te'vil kavramları etrafında tartışır. bk. Hâris b. Esed el-Muhâsibî, er-Riâye li-hukûkillah, thk. Abdulhalim Mahmud, (Kahire: Dârü'l-Maarif, 1990),106-109; Hâris b. Esed el-Muhâsibî, ÂdâbûnNüfûs, thk. Abdülkadir Ahmed Atae (Beyrut: Dârü’l-Cil, 1987), 63-64; Bağdâdî, Resâil, 9-17, 52-54. 87. Kuşeyrî, er-Risâle, 27.

88. Kuşeyrî̀nin bu çerçevede sûfî portrelerde yer verdiği bir başka tasavvuf yoluna giriş hikâyesi Şakîk el-Belhı̂’nin isâr davranışıdır. "Hâtem Asamm anlatıyor: "Şakîk b. İbrâhim zengin bir zat idi. Fütüvvet ve mürüvvet gösteriyor, malını cömertçe harcıyor, gençlerle düşüp kalkıyordu. Bu sırada Belh Emiri Ali b. İsa Mâhan idi. Emir köpeğini alarak ava gitmekten hoşlanırdı. Bir gün köpeklerinden birini kaybetmişti. Köpeğin bir adam tarafından çalındığı fesatçılar tarafından iddia edildi. Bu adam Şakîk'in komşusu idi. Adam aranmakta olduğunu duyunca korktu ve kaçtı. Eman dileyerek Şakîk'in evine girdi. Şakîk kalktı, Emir'in yanına gitti ve şöyle dedi: Bu adamı yakasını bırakın, köpek benim yanımdadır, üç güne kadar size teslim edeceğim, dedi. Adamın yakasını bıraktılar. Şakîk, Emir'in yanında ne yapacağını düşüne düşüne ayrıldı. Üçüncü gün olunca Şakîk'in dostlarından olup o sırada seferde bulunan bir zat Belh’e dönmüş, yolda 
Bu iki şarta binaen ortaya konan ameller, Allah'ın insana saflaşmış bir hâl yahut vârid göndermesiyle neticelenebilir. Böylece insanın kemâl süreci başlayabilir.

\section{7. İnsanın Yetkinlik Sürecinde Başlangıç-Son İlişkisi}

Erken dönem tasavvuf literatüründe sûfîlerin tasavvufu benimsemelerinde dikkati çeken bir diğer husus, kemâl sürecinin kademeli olarak tasviridir. Buna göre, sâlikin tek bir yetkinlik sürecinden ziyade iç içe geçmiş, sürekli ve daha mütekâmil olana doğru seyretmesi muhtemel birden fazla kemâlin iç içeliğinden bahsetmek mümkündür. Kuşeyrî bu hususa işaret etmek üzere Bâyezîd-i Bistâmî̉nin şu başlangıç hikâyesine atıfta bulunur:

"Ümmi Bistâmî diyor ki: Babam Bâyezîd'e (sülûkunun) başlangıcı ve zühdü hakkında sorulmuş. O da: Zühdün bir tek menzili yoktur ki, bir tek cevap vereyim, demiş. Niçin? Sorusuna ise şu cevabı vermişti: Çünkü ben zühdde üç gün kaldım, dördüncü gün zühdden çıktım. İlk gün dünya ve dünyada olan şeylere karşı zâhid oldum. İkinci gün âhirete ve orada bulunan şeylere karşı zâhid oldum. Üçüncü gün Allah'tan başka ne varsa hepsine karşı zâhid oldum. Dördüncü gün olunca bana Allah'tan başka bir şey kalmadı. Anladım. O zaman hâtiften gelen bir sesin bana: Ey Bâyezîd! Bizimle bulunmaya takatin yetmez, dediğini işittim ve maksadım işte bu idi, dedim. Aynı ses bu sefer: (maksadını ve isteğini) buldun, buldun diye hitap etti." ${ }^{\$ 9}$

Yukarıdaki anlatıda dikkat çeken birkaç husus bulunmaktadır. İlk olarak, Bâyezîd, tasavvufî anlamda yetkinleşme sürecini zühd ile ifade eder.

boynunda halka bulunan bir av köpeği bulmuş, bunu Şakîk'e hediye etmeliyim, zira o gençlerle düşüp kalkıyor diye düşünmüş, köpeği almış ve Şakîk'e getirmişti. Şakîk köpeği görünce, bunun kaybolan köpek olduğunu anladı ve memnun oldu, köpeği aldı, Emir'e götürdü ve taahhüdünden kurtuldu. Bu hâdise üzerine Allah, Şakîk'e bir uyanış (intibâh) nasip etti. Yaptıklarına tevbe etti ve zühd yolunu tuttu." Kuşeyrî, er-Risâle, 36-37.

89. Kuşeyrî, er-Risâle, 38. Hücvîrî farklı bir rivâyet aktarır: "Bir kere Mekke'de bulunmuştum. Sadece Beyt'i görmüş ve haccım makbul değil, çünkü daha evvel de bu cinsten pek çok taş görmüştüm, dedim. Bir defa daha Mekke’ye gittim. Bu sefer hem evi hem de evin sahibini yani Allah’ı gördüm ve dedim ki: Henüz tevhidin hakikati yoktur. Üçüncü bir kere daha gittim. Bu defa herşeyi evin sahibi olarak gördüm. Evi göremedim. O vakit sırrıma ve rûhuma şöyle nida olundu: Ey Bayezid! Eğger nefsini görmezsen tüm kâinatı görsen bile müşrik olmazsın. Bilakis bütün kâinatı görmesen de nefsini görsen müşrik olursun! İşte o vakit, tevbe ettim ve varlı̆̆ımı görmekten de tevbe ettim.” Hücvîrî, Keşfü'l-Mahcûb, 205-206. 
İkinci olarak zühdün kendi içinde üçlü hiyerarşik bir yapısı olduğuna vurguda bulunur. Buna göre zühdün birinci basamağı dünyayı terk, ikinci basamağı âhireti terk, üçüncü basamağ 1 Allah'tan başka her ne varsa hepsini terk etmektir. Bu sıralama tasavvufî düşüncenin ana prensipleri ile uyuşmakla birlikte insanın nihai gayesini göstermesi bakımından ayrıca önemlidir. İnsanın nihai gayesi, Allah dışındaki tüm ilgi ve alakaları terk etmek anlamında zühd içerisinde olmaktır. Bu anlamda zühd, sadece terk anlamına değil aksine her an Allah ile olma haline atıfta bulunmaktadır. Peki tasavvufî düşünceye göre insanın kemâl süreci sürekli artarak ilerleyen doğrusal bir hat üzerinde mi devam eder yoksa belirli şartlarda duraksayan, gerileyen ve daha sonra yeniden ilerleyen bir çizgide mi değerlendirilir? Kuşeyrî̀ye göre insan kemâl sürecinde duraksayabilir yahut gerileyebilir. Başta işaret edilen telvîn hali yahut tahavvül hakkında Kuşeyrî̀nin aktardığı iki rivâyet aşağıdaki gibidir:

"Derler ki Ebû Amr b. Nüceyd (tasavvuf yolunun) başlangıcında Ebû Osman'ın sohbet meclislerine devam ederdi. Sözlerinin tesirinde kaldı ve tevbe etti. Sonra bir ara işi gevşetti. Ebû Osman'ı gördükçe ondan kaçıyor ve meclislerine devam etmiyordu. Bir gün yolda Ebû Osman'la karşılaştı, yolu değiştirdi. Başka bir yola saptı. Ebû Osman onu takip etmeye başladı ve nihayet yakaladı: Evladım, sadece günahsız olduğun zaman seni sevenle arkadaşlık etme! Ebû Osman sadece bu nevi hallerinde (gevşeklik) sana faydalı olur dedi. Bunun üzerine Ebu Amr tevbe etti. Önceki (müritlik) haline döndü ve bunu başarı ile devam ettirdi." ${ }^{\circ 0}$

“Ebû Ali Dekkâk’’n şunu söylediğini işitmiştim: Müritlerden biri tevbe etmiş, sonra işi gevşeterek müritliğe ara vermişti. Bir gün acaba tevbe haline dönsem bunun hükmü nasıl olur, diye düşünürken hâtiften bir ses ona: Ey Falan bize itaat ettin, biz de sana teşekkür ettik. Sonra bizi terk ettin, biz de sana mühlet verdik. Eğer bize dönersen seni kabul ederiz, dedi. Bunun üzerine genç (müritlik) haline döndü ve bunda başarılı oldu." ${ }^{\text {1 }}$ 
Sufinge

78

을

\section{Sonuç}

Erken dönem tasavvuf literatüründe "İnsanın kemâl süreci nasıl başlar?” sorusundan hareketle vazettiğimiz tartışmanın neticeleri hakkında şunları söylemek mümkündür. İnsanın kemâl süreci sistematik bir tedrîs ve tâlim sürecini zorunlu kılan nazarî bir araştırmanın sonucunda ulaşılan bir bulmaya değil aksine insanın tabiatında mündemiç ve fakat unutulmuş bir gâyenin hatırlanmasına dayanmaktadır. Sûfi portrelerde insanın kemâl süreci, farklı bir dine mensup bir kimsenin tasavvuf aracılığıyla (mürşîd) İslâmiyet'i benimsemesi, sâlikin ilk defa tasavvufa yönelişi yahut sülûk süreci içinde kademeli olarak yetkinleşmesi şeklinde betimlenir. Bununla birlikte Kuşeyrî̀nin din değiştirme zemininde aktardığı rivâyetlerin çoğunluğunun ortak noktasını kerâmet oluştururken, diğer başlangıç hikâyelerinin sebepleri ise Allah'ın inâyeti, duyular (çoğunlukla işitme ve görme) aracıllğıyla idrak ile ihlâsa üzere gerçekleştirilen eylem olduğu söylenebilir.

İnsanın kemâl sürecinin başlangıcı ile ilgili bir diğer tespit, tasavvufa yönelen sûfîlerin nihai gayelerinin rızık değil de marifet olduğunu idrak etmeleridir. Bu anlamıyla söz konusu rivâyetler aynı zamanda içinde bulunulan toplumda ahlâkî bakımdan yozlaşan insana yönelik bir eleştiri olarak da okunabilir. İnsanın kemâl sürecinin başlangıcı ile sonu arasında doğrusal ve determinist bir ilişki bulunmamaktadır. Sûfîlerin tasavvufa yönelişlerini içeren rivâyetlere göre sülûk sürecinde duraksama, gerileme, yeniden dönme yahut tamamen yoldan sapmalar olabilir. Bu tespit aynı zamanda sûfî müelliflerin insanın akıbeti hakkında benimsediği uhrevî kurtuluştan emin olmamaktan kaynaklanan havf ve recâ ile va'dvaîd konusundaki yaklaşımlarıyla da uyumludur. Sûfî portrelerde tasavvufa yönelenlerin gerekçeleri her ne kadar benzerlikler içerse de insan tipolojileri bakımından dikkat çekici bir çeşitlilik arz etmektedir. Kimisi fakirleri gözeten bir eşkıya iken kimisi bir melikin oğlu yahut sıradan bir insan olarak betimlenmektedir. Dolayısıyla sûfî başlangıç hikâyelerinde insânî yetkinlik konusunda belli bir seçkincilik fikrine rastlanmamaktadır.

Sûfî başlangıç hikâyeleri aynı zamanda kendi dönemine yönelik bir toplum ve insan eleştirisini de içinde barındırmaktadır. Varoluş gayesini unutarak rızık peşine düşen, şan, şöhret ve makamı arzulayan yahut ahlâkî eylemlerinin gerekçesini Allah dışındaki ilkelere göre temellendiren ve bilgi-eylem birlikteliğini gözetmeyen insan tipolojileri dolaylı 
bir şekilde tenkit edilmektedir. Bu anlamıyla sâlikin tasavvufa yönelişinin başlangıcında terk ettiği ve yöneldiği unsurlar aynı zamanda ahlâkî bozuluşa maruz kalan insanın nasıl yeniden erdemli bir varlığa dönüşeceğinin ana hatlarını içeren bir izlek işlevi üstlenebilir.

Son olarak tasavvufa yönelen sûfîlerin girdikleri yolu tevbe, zühd, terk, Allah'a yönelme ve yeniden Müslüman olma gibi terimlerle ifade etmeleri, erken dönem tasavvuf literatüründe tasavvufun ilk olarak nasıl anlaşıldığı ve ortaya çıktığ 1 konusunda birtakım ipuçlar verebilir. Kuşeyrî̉nin Risâle adlı eserinden hareketle sûfîlerin tasavvufa yönelişlerini ifade etmek için en çok tercih ettikleri terim tevbe olmakla birlikte, yeniden Müslüman olma ifadesi ise en dikkat çekici olanıdır. Sıklıkla tekrarlanan olmak bakımından ikinci sırada gelen terimler terk ve zühd kelimeleridir. Tasavvufa yönelen sûfî sahip olduğu mal yahut mevkiyi terk ederek, genellikle Mekke'ye doğru bir seyahate çıkmakta ve yaşamının geri kalan kısmını Hz. Peygamber'e komşu olarak (mücâvirlik) sürdürmektedir. Başlangıç hikâyelerinde dikkat çeken son kelime ise hikmet kavramıdır. Mansûr b. Ammâr'ın tasavvufa yönelişi, Allah tarafından kendisine hikmet kapısının açılması olarak betimlenmektedir ki, bu durum erken dönem sûfî metinlerinde hikmetin tasavvuf yerine kullanıldığının bir göstergesidir.

Şekil 1: Kuşeyrî̀nin er-Risâle adlı eserinde sûfîlerin tasavvufa yönelişlerini ifade ederken kullandıkları terimler:

\begin{tabular}{|l|l|l|l|}
\hline Sıra & Sûfî & $\begin{array}{l}\text { Sûfîlerin Tasavvufa } \\
\text { Yönelişlerini İfade } \\
\text { Etmek I̧in Kullandıkları } \\
\text { Terim/ler }\end{array}$ & Sayfa \\
\hline 1 & Ebû Kasım Nasrabâzî & Yeniden Müslüman olmak & s. $16-17$. \\
\hline 2 & Ebû Osman Mağribî & Yeniden Müslüman olmak & s. 15. \\
\hline 3 & Ebû Hafs Nişâbûrî & Terk & s. 105. \\
\hline 4 & Ebû Nasr Müezzin & Terk & s. 105. \\
\hline 5 & Ebû Süleyman Dârânî & Yola girmek & s. 128. \\
\hline 6 & Ma'ruf el-Kerhî & Allah'a yönelmek & s. 27. \\
\hline 7 & Ebû Amr b. Nüceyd & Tevbe etmek & s. $128-129$. \\
\hline 8 & Genç (Belirsiz) & Tevbe etmek & s. 129. \\
\hline 9 & Zünnûn el-Misrî & Tevbe etmek & s. $24,409$. \\
\hline 10 & Fudayl b. İyâz & Tevbe etmek & s. 25. \\
\hline
\end{tabular}


Sufive

80



Aynur SINGGIN

\begin{tabular}{|l|l|l|l|}
\hline 11 & Bişr el-Hâfî̀ & Tevbe etmek & s. 30. \\
\hline 12 & Şiblî & Tevbe etmek & s. 71. \\
\hline 13 & Adam (Belirsiz) & Tevbe etmek & s. 411. \\
\hline 14 & Şakîk el-Belhî & Tevbe /Zühd & s. 36. \\
\hline 15 & Mansûr b. Ammâr & Tevbe/ Hikmet & s. 48. \\
\hline 16 & Dâvûd et-Tâî & Zühd & s. 34. \\
\hline 17 & Bâyezîd-i Bistâmî & Zühd & s. 38. \\
\hline
\end{tabular}

Çıkar Çatışması / Conflict of Interest: Yazarlar çıkar çatışması olmadığını beyan etmiştir. / The authors declared that there is no conflict of interest.

Finansal Destek / Grant Support: Yazarlar bu çalışma için finansal destek almadıklarını beyan etmiştir. / The authors declared that this study has received no financial support.

\section{Kaynakça}

Akkuş, Süleyman. "Abdülkerim b. Hevâzin el-Kuşeyrî̀nin Bir Risâlesi”. Sakarya Üniversitesi İlahiyat Fakültesi Dergisi 2/89 (2000), 112.

Bağdâdî, Cüneyd. Resâilü’l-Cüneyd. thk. Ali Hasan Abdülkadir. Kâhire: Darü'l-Kütübi'lMisriyye, 1988.

Başer, Hacı Bayram. "Yükümlü Varlıktan Varlığın Gayesi Olan İnsana: Tasavvufta İnsan Tanımlarının Dönüşümü Üzerine”. İnsan Nedir?: İslâm Düşüncesinde İnsan Tasavvurları. ed. Ömer Türker - Halil İbrahim Üçer. İstanbul: İlem Yayınları, 2019.

Başer, Hacı Bayram. Şeriat ve Hakîkat: Tasavvufun Teşekkül Süreci. İstanbul: Klasik Yayınları, 2017. Câmî, Abdurrahman. Nefahâtüll-Üns: Evliyâ Menkıbeleri. çev. Lâmiî Çelebî. haz. Süleyman Uludağ - Mustafa Kara. İstanbul: Marifet Yayınları, 2001.

Cengiz, Muammer. “Tasavvuf Tarihinde Elest Misâkına Dair Yorumlar”. Uluslararası Sosyal Araştırmalar Dergisi 10/50 (Haziran 2017), 906-907.

Ceyhan, Semih. "Semâ". Türkiye Diyanet Vakfi İslâm Ansiklopedisi. 9/455-457. İstanbul: TDV Yayınları, 2009.

Demirli, Ekrem. “Kuşeyrî̀den İbnü’l Arabî̀ye İşâ̂î Yorumculuk Hakkında Bir Değerlendirme: İşârî Yorumdan Tahkîke Doğru Kur’ân-1 Kerim Yolculuğunun Gelişimi”. Atatürk Üniversitesi İlahiyat Fakültesi Dergisi 40 (2013), 121-141.

Demirli, Ekrem. "Sarih Akıl ile Sahih Fitrat Arasında Selim Duyular: İnsanın Hakikat Arayışında Duyuların Yeri”. Erişim 12 Ocak 2021. https://www.sabahulkesi.com/ 
Gül, Halime. İbrahim b. Edhem ve Tasavvuf Tarihindeki Yeri. Konya: Selçuk Üniversitesi, Sosyal Bilimler Enstitüsü, Yüksek Lisans Tezi 2008.

Hücvirî, Ali b. Osman. Keş̧ü’l-Mahcûb: Hakîkat Bilgisi. haz. Süleyman Uludağ. İstanbul: Dergâh Yayınları, 1996.

Kelâbâzî. Muhammed b. İbrâhim. et-Taarruf: Doğuş Devrinde Tasavvuf. çev. Süleyman Uludağ. İstanbul: Dergâh yayınları, 2016.

Khalil, Atif. "A Note on Interior Conversion in Early Sufism and Ibrahım b. Adham's Entry into the Way”. Journal of Sufi Studies. 5/2 (Nowember 2016), 189-198.

Kuşeyrî, Abdülkerîm b. Hevâzin. er-Risâletü’l-Kuşeyriyye. haz. Halil el-Mansûr. Beyrût: Dârü'lKütübi'l-ìlmiyye 1422/2001.

Kuşeyrî, Abdülkerîm b. Hevâzin. er-Risâle: Tasavvuf İlmine Dair Kuşeyrî Risâlesi. çev. Süleyman Uludağ. İstanbul: Dergâh Yayınları, 2003.

Kuşeyrî, Abdülkerîm b. Hevâzin. Lüma fi'l-İtikad. çev. Ercan Alkan. Tasavvuf: İlmî ve Akademik Araştırma Dergisi 12/28 (2011), 193-198.

Meçin, Mahmut. “Felsefe ve Tasavvufta Sefer Metaforu: Aklî ve Manevî Yolculuk”. Atatürk Üniversitesi İlahiyat Fakültesi İlahiyat Tetkikleri Dergisi 54 (2020), 329-353.

Meier, Frietz. “Kuşeyrî’nin Tertibü’s-Sülûku”. çev. Eyüp Kaya. Tasavvuf: İlmi ve Akademik Araştırma Dergisi. 4/10 (2003), 363-375.

Muhâsibî, Hâris b. Esed. Âdâbû'n-Nüfûs, thk. Abdülkadir Ahmed Ata. Beyrut: Dârü’l-Cil, 1987.

Muhâsibî, Hâris b. Esed. el-Akl ve Fehmu’l-Kurân. thk. Hüseyin Kuvvetli. b.y.: Dârü'l-Fikr, 1971.

Muhâsibî, Hâris b. Esed. el-Akl ve Fehmü'l Kur'ân: Akıl ve Kur'ân’ı Anlamak. thk. Dr. Hüseyin el-Kuvvetli. çev. Veysel Akdoğan. İstanbul: İşaret Yayınları, 2018.

Muhâsibî, Hâris b. Esed. er-Riâye li-hukûkillah. thk. Abdulhalim Mahmud. Kahire: Dârü'lMaarif, 1990.

Muhâsibî, Hâris b. Esed. Şerefü>l-Akl ve Mahiyyetuhu. thk. Mustafa Abdülkadir Ata. Beyrut: Dârü’l-Kütübi'l-İlmiyye, 1986/1406.

Özturan, Hümeyra. Ahlâk Felsefesinin Temel Problemleri. İstanbul: İlem Yayınları, 2019.

Reis, Bedriye. “Kuşeyrî̀nin Letâifü’l-Işârâtı Bağlamında Kalbin İdraki”. İnsan ve Toplum Bilimleri Araştırma Dergisi 8 (2019), 537-558.

Serrâc, Ebû Nasr Abdullah. el-Lüma': İslâm Tasavvufu. çev. Hasan Kâmil Yılmaz. İstanbul: Erkam Yayınları, 2019.

Şık, İsmail. «Bir Mutasavvıf Olarak Kuşeyrî>nin Kelâmî Görüşleri». İslâmi İlimler Dergisi 4/12 (2009), 257-274.

Şık, İsmail. “Kuşeyrî̀nin “Luma’ fi’l-İtikâd” Adlı Akâid Risalesinin Çeviri ve Değerlendirilmesi”. Çukurova Üniversitesi İlahiyat Fakültesi Dergisi. 8/2 (Temmuz-Aralık 2008), 205-214.

Tan, M. Nedim. “Tasavvuf Istılahlarının Teşekkül Dönemi Açısından Şakîk-i Belhî’nin Âdâbü’lİbâdât'ı”. Marmara Üniversitesi İlahiyat Fakültesi Dergisi 45 (2013), 155-190. 


\section{Sufive}

82

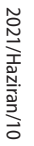

\section{Aynur SINGGIN}

Türk, Hamide. Marûf el-Kerhî: Hayatı, Tasavvufî Görüşleri ve Menâkıbu Marûf el-Kerhî İsimli Eser. Konya: Selçuk Üniversitesi, Sosyal Bilimler Enstitüsü, Yüksek Lisans Tezi, 2005.

Uludağ, Süleyman. Tasavvuf Terimleri Sözlüğü. İstanbul: Kabalcı Yayınevi, 2001.

Yaman, Hikmet. “İsmi Olmayan Bir Hakikatten Hakikati Olmayan Bir İsme Varan Yolculuk: Oryantalist Çalışmalarda Tasavvufun Menşeine Dair Tartışmalar Üzerine Bir Değerlendirme”. Akademik İslâm Araştırmaları Dergisi 1 (2016), 15-48.

Yılmaz, Ömer. İbrahim Kurani Hayatı, Eserlerive Tasavvuf Anlayışı. İstanbul: İnsan Yayınları, 2005. 